DIW BERLIN

Discussion

Papers

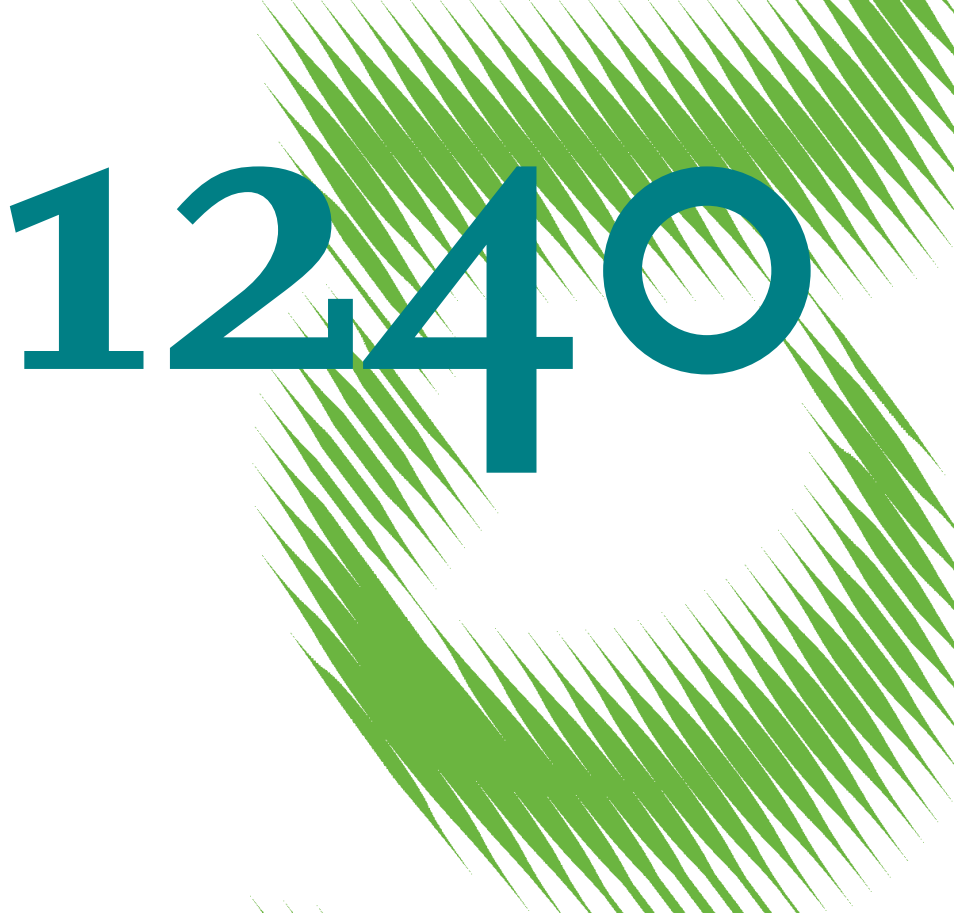

MMI

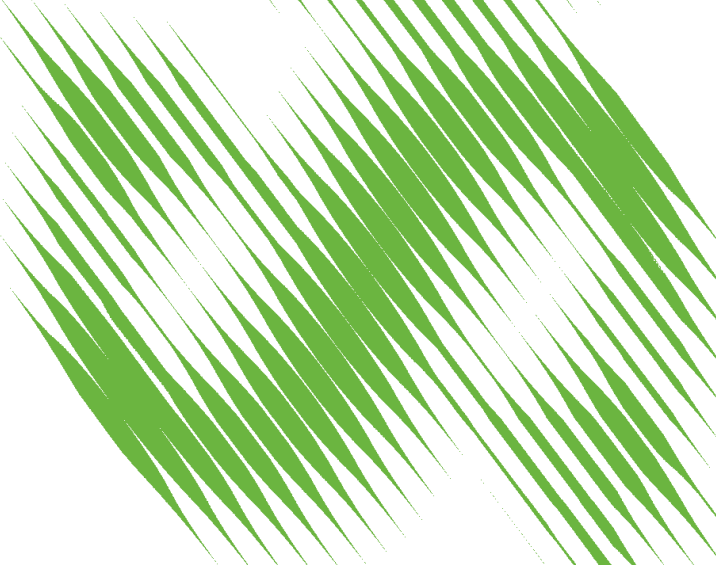

Risk and Returns to Educational Fields

A Financial Asset Approach to Vocational and Academic Education 
Opinions expressed in this paper are those of the author(s) and do not necessarily reflect views of the institute.

IMPRESSUM

(C) DIW Berlin, 2012

DIW Berlin

German Institute for Economic Research

Mohrenstr. 58

10117 Berlin

Tel. $+49(30) 89789-0$

Fax +49 (30) $89789-200$

http://www.diw.de

ISSN print edition $1433-0210$

ISSN electronic edition 1619-4535

Papers can be downloaded free of charge from the DIW Berlin website:

http://www.diw.de/discussionpapers

Discussion Papers of DIW Berlin are indexed in RePEc and SSRN:

http://ideas.repec.org/s/diw/diwwpp.html

http://www.ssrn.com/link/DIW-Berlin-German-Inst-Econ-Res.html 


\title{
Risks and Returns to Educational Fields - A Financial Asset Approach to Vocational and Academic Education
}

\author{
Daniela Glocker \\ Centre for Economic Performance/LSE \\ Email: D.Glocker@lse.ac.uk \\ Johanna Storck \\ DIW Berlin \\ Email: jstorck@diw.de
}

This Version: August 29, 2012

Keywords: $\quad$ Educational Choice, Human Capital Investment, Returns to Schooling, Mean-Variance Analysis

JEL classification: I21, J24 
Abstract: Applying a financial assets approach, we analyze the returns and earnings risk of investments into different types of human capital. Even though the returns from investing in human capital are extensively studied, little is known about the properties of the returns to different types of human capital within a given educational path. Using information from the German Micro Census, we estimate the risk and returns to around 70 fields of education and differentiate between vocational and academic education. We identify fields of education that are efficient investment goods, i.e. high returns at a given level of risk, and fields that are chosen for other (non-monetary) reasons. Furthermore, we rank fields of education by their return per unit of risk and find that university education is not always superior to other educational paths.

Acknowledgments: We would like to thank Frank Fossen, Ronny Freier,Nils Saniter and Viktor Steiner. Comments of the participants of the Cluster Seminar at DIW Berlin, the Economic Policy Seminar at FU Berlin and IWAEE at Catanzaro are also gratefully acknowledged. The usual disclaimer applies. 


\section{Introduction}

The positive effects of investments in human capital on the level and evolution of earnings, employment, and other aspects of well-being is one of the most robust and important empirical findings in labor economics (see e.g. Blundell, Dearden, Meghir, and Sianesi, 1999; Oreopoulos and Salvanes, 2011; Psacharopoulos and Patrinos, 2004). In developed countries, education is an important resource for the economy and assumed to be one of the key determinants in technological development, production and, thus, economic growth. Therefore, politicians aim at increasing the population's educational level (see e.g. EUROPE 2020 - indicators (European Comission, 2010)). As increasing the countries overall educational level requires individuals to invest in their education, researchers focus on the individual's (economic) benefits of education, mainly the increase in earnings due to investments into more education.

Even though the returns from investing in human capital in general are widely studied, little is known about the properties at a more disaggregated level, i.e. field specific returns to education. Standard economic models of schooling decisions (Becker, 1964; Mincer, 1974) model the average returns to years of schooling by comparing future income streams to the costs associated with an additional year of schooling but do not differentiate between different fields. To overcome the assumption of homogeneity of human capital investments, we differentiate between fields of education within and across levels of education. Borrowing from financial economics models (see e.g. Cochrane, 2001), we contribute to the literature on human capital investment by differentiating between a large variety of educational fields and by incorporating the unexplained variance of the returns, the earnings risk, into the evaluation of the benefits from education.

To learn more about the properties of returns to different types of human capital and how they compare across fields is important from both a theoretical and a political perspective. From a theoretical perspective variations in returns to educations across fields and the earnings variation within a field have important consequences for models on educational choice that usually only consider aggregated earnings streams at different levels of education as explanatory variable. By aggregating over different fields of education one might, for example, overstate the additional value of a further year of education if the additional year of education is spent in an educational program with low labor market returns.

From a political perspective it is important to know the financial attractiveness of an educational field for various reasons. First, our results can serve as an instrument to evaluate the demand for graduates on the labor market. In Germany, for example, it is controversially discussed as to whether there is a lack of graduates from engineering fields or more broadly from MINT-fields ${ }^{1}$. While some experts claim that there is a lack of skilled engineers and demand that politicians take action (see e.g. Anger, Koppel, and Plünnecke, 2011), others do not share

\footnotetext{
${ }^{1}$ MINT-fields include fields in mathematic, computer science, engineering, natural science and other technical fields.
} 
this opinion (see e.g. Brenke, 2010). Identifying the field specific returns and associated risks could serve as a tool to evaluate the demand for graduates of a certain field of education on the labor market, with high earnings and low levels of earnings variance indicating a high demand for skilled labor in a specific field.

Second, the main impact politicians have on individual investment can be assumed to be through the costs of the investment or by providing information on the benefits of the investment in education. One factor through which politics influence educational investments are tuition fees. Discussions about tuition fees are usually charged with the argument that the main beneficiary of education is the individual (in addition to some positive externalities), so the investment does not have to be free of charge as the individual will capture the returns to his/her investment later in life. Thus, fields with high labor market returns might be charged higher fees, while there could be an interest to keep tuition fees of subjects with smaller labor market returns but high non-pecuniary returns (for example, arts) or high social returns (for example, education) low. It could further be assumed that there is an information deficit among prospective students or incorrect perceptions about returns to fields and levels of education, which lead to inefficient sorting into the fields. In that case politicians could rely on the estimates when informing about the financial attractiveness of the various fields of education.

Altering the expected returns to different fields of education in order to navigating educational investments of prospective students, can be assumed to be an effective political instrument. Existing models estimating the effect of expected earnings streams in different fields of education on the college major choice suggest that this choice is partly guided by expected earnings and further by non-pecuniary factors as preferences or ability (see e.g. Arcidiacono, Hotz, and Kang, 2011; Arcidiacono, 2004; Berger, 1988; Beffy, Fougre, and Arnaud, 2012; Boudarbat and Montmarquette, 2009).

The risk associated with different types of education should not be neglected. The question of whether, empirically, human capital investments are risky is addressed by Becker (1964), who notes that there is more earnings variation among college graduates than among high school graduates. Literature on the decision to pursue higher education, incorporating risk, originates with Levhari and Weiss (1974). They find that increasing risk, i.e. the variance in the payoff for education, reduces investment to education. Subsequent studies similarly find that reducing uncertainty in returns increases educational participation (see e.g. Hartog and Vijverberg, 2007; Carneiro, Hansen, and Heckman, 2003; Fossen and Glocker, 2011).

The highest expected earnings are usually found for fields in social science (mainly business and law) and medical subjects, while humanities and arts are rather unattractive investments in terms of monetary returns (Walker and Zhu, 2011). ${ }^{2}$ The authors estimate the returns to groups of subjects but the variance of the returns within the group of fields is not considered.

\footnotetext{
${ }^{2}$ Other studies are Ammermüller and Weber (2005) and Wahrenburg and Weldi (2007) for Germany, Arcidiacono (2004) for the US, Boudarbat and Montmarquette (2009) for Canada, Kelly, O'Connell, and Smyth (2010) for Ireland and Chevalier (2011) for the UK.
} 
Relatively little research, thus, tries to understand how the risk-return trade-off for different human capital investments compare at the margin. Palacios-Huerta (2003) is the first to empirically analyze risk properties of various human capital returns. He presents an empirical comparison of risk adjusted human capital investments to financial investments. Christiansen, Joensen, and Nielsen (2007) take up his approach and analyze the risk-return trade-off in human capital investments with Danish labor market data. In both studies, the authors compare the risk properties of human capital assets by applying a framework that is standard for the analysis of financial assets.

We contribute to this stream of literature by comparing the risk and returns to a large number of educational fields in Germany. Germany provides a good framework for studying returns and risk properties to different types of education for various reasons: In Germany upper secondary high school graduates can choose between vocational education, education at a university of applied science or at a university. These educational paths have different characteristics, for example, different lengths of study, qualification levels or levels of specialization. Despite the different characteristics, they offer, in a lot of cases, similar fields of education. For example, a person interested in business or manufacturing can choose between all three paths. Hence, for a decision maker it is not only interesting to know how earnings and earnings risk vary across the paths on average but also how earnings vary between the paths for one specific field. This variation in educational choices also allows us to restrict our sample to upper secondary school graduates who obtained a university entrance certificate. Due to this sample selection, a bias stemming from sorting into the fields based on ability can be assumed to be relatively small. The group can be assumed to have a rather homogenous level of general ability. Beyond the educational framework, it is interesting to evaluate the financial performance of fields of education in Germany because of the controversially discussed lack of skilled graduates in some fields of education.

Using a large German data set, the German Micro Census, we are able to estimate the returns and earnings variances for about 70 fields of education. We estimate the returns to different fields of education by extending the standard Mincer wage equation to allow for different fields of study. By analyzing the risk-return trade-off for a large number of fields, we identify fields that are efficient in terms of investment goods and fields that are likely to be chosen for other reasons (consumption purposes). Because students have different preferences and abilities, we also look at the efficiency of different levels of educations within a certain group of fields (e.g. engineering fields). For instance, for someone interested in engineering, we find that a university degree in manufacturing engineering is an efficient investment as there is no other engineering field that earns a higher rate of return with the same level of earnings variation. Similarly an applied science degree in precision engineering should be chosen over a university degree in electrical engineering because it yields about the same returns but at a lower variation level. ${ }^{3}$ We find that fields in all educational paths can be efficient investments. Hence, the decision about the

\footnotetext{
${ }^{3}$ This is true only under the standard assumption that individuals are risk averse.
} 
level of education as well as the field of education is important when deciding about investments in education.

The paper is structured as follows: The following section explains the methodology for estimating the performance measures. Section 3 describes our dataset. Section 4 provides the results of our analysis, followed by the conclusion in Section 5 .

\section{Empirical model and methodology}

\subsection{Performance measure}

As we analyze different fields of education in terms of their investment value, we need to find an adequate measure for the efficiency of each field. The literature analyzing the returns to educational subjects focuses on the returns themselves and tends to neglect the risk associated with the different investments (see e.g. Wahrenburg and Weldi, 2007). However, this might bias the evaluation of the investment value, as the risk of an investment largely influences the investment decision (see Hartog and Vijverberg, 2007; Carneiro, Hansen, and Heckman, 2003; Fossen and Glocker, 2011). With respect to the educational decision, one might think of unemployment risk associated with different educational qualifications that add some uncertainty with regard to the expected returns. The variation of unemployment risk across educational qualification is well documented, (see e.g. Mincer, 1991; Riddell and Song, 2011; Reinberg and Hummel, 2007). The unemployment risk may not only vary between different educational paths, but also between the field of education majored in.

Interpreting the different fields of education as different investment strategies, we use a standard financial economics approach: The mean-variance model of Markowitz (1952). In the model, assuming that the returns are normally distributed, investors only consider the expected returns and their variances in their decision making process. Graphing the expected returns and their standard deviation in a so-called mean-variance plot exhibits all feasible investments. Depending on the individual's utility function (increasing with returns and risk-avoidance), the optimal investment strategy lies on the efficient frontier, i.e. the investment which exhibits the highest returns for a given risk. We assume investment in education to be a discrete choice. Portfolios of educations are not considered in this study. For that reason, the mean-variance plot for human capital investments is a scatter-plot whereas the empirical efficient frontier for financial assets is a continuous line.

Following Christiansen, Joensen, and Nielsen (2007) we use a modified version of the Sharperatio (Sharpe, 1966) to formally describe those plots and to rank the different educational investments. The Sharpe-ratio is a return to variability measure that also uses the expected (excess) returns compared to a risk free alternative, standardized with its standard deviation. Since a risk free return in the context of educational choices is not straight forward, we compare the 
returns of a certain educational field with the (risk free) sample average returns $\bar{R}$ over all fields as a proxy for the true population average returns:

$$
S_{j}=\frac{E\left[R_{j}-\bar{R}\right]}{\sqrt{V A R\left[R_{j}-\bar{R}\right]}} .
$$

The Sharpe-ratio $S_{j}$ then indicates the efficiency gain or loss from investing into educational field $j$ compared to the average. Thus, a higher value of the Sharpe-ratio relates to a better performance of the investment.

\subsection{Measuring the returns}

To derive our performance measure, we need the returns associated with a certain field of education. Thus, we calculate the individual hourly wages in each educational field and use this information to estimate field average returns.

To obtain the returns, we use a modified version of the standard Mincer wage regression (Mincer, 1974). We allow the $\log$ hourly wage $(\log (W))$ of individual $i$ to non-linearly increase with age. We prefer age over experience, as we do not observe the true work experience. A constructed measure of potential experience as a linear combination of age, years of education and the general school starting age could bias our results since possible unemployment spells are not accounted for. However, our constructed measure also neglects the information on unemployment experience, which is potentially correlated to the fields of study and may effect wages due to human capital depreciation. We try to attenuate this omitted variable bias by including information on tenure in the recent job in our model.

As with the standard Mincer returns to schooling approach, estimating field specific returns might result in several problems (see Altonji, Blom, and Meghir, 2012, for a detailed overview). A major concern, first described by Willis and Rosen (1979), and frequently discussed in the context of estimating returns to education, addresses the problem of unobserved variables that might be correlated with the educational variable, i.e. motivation or ability. Unfortunately, our dataset neither includes ability measures nor retrospective information that would allow us to model the selection process into educational fields. To keep a possible ability bias small, we constrain our sample to students that passed the university entrance examination (Abitur) such that variation due to unobserved ability is reduced. Studies analyzing the effect of educational qualifications ${ }^{4}$ on wages, tend to find a significant effect due to ability sorting (see e.g. Carneiro, Hansen, and Heckman, 2003). In contrast to these findings, studies focusing on college majors including measures for ability conclude, that such a bias due to omitted ability variables is rather small (Berger, 1988; Arcidiacono, 2004).

\footnotetext{
${ }^{4}$ Educational qualification referring to the standard Mincerian approach of an additional year of schooling, but also to studies estimating the returns of different education qualification like university or college degrees.
} 
The second problem we face is possible endogeneity of educational fields. We may observe the individuals in the respective fields, because they chose that field according to their expectations about the associated returns. Arcidiacono, Hotz, and Kang (2011) show, that an increase in the expected earnings in a certain field of education has a significant positive effect on choosing this major. A possible solution for this problem would be to instrument the educational field variables, but with our dataset we are not able to construct such instrumental variables to account for this possible endogeneity. When interpreting our finding, we should keep the literature findings in mind, which indicate that our return estimates might be biased upwards.

We estimate the earnings by applying a OLS model for the working population: ${ }^{5}$

$$
\begin{aligned}
\log \left(W_{i}\right)= & \sum_{j=1}^{J} \alpha_{0 j} F_{i} L_{i}+\sum_{l=1}^{L} \alpha_{1 l} \operatorname{age}_{i} L_{i}+\sum_{l=1}^{L} \alpha_{2 l} \operatorname{age}_{i}^{2} L_{i}+\beta X_{i}+\epsilon_{i}, \\
& \text { with } \\
& j=1, \ldots, J \text { and } l=1, \ldots, L \\
& \text { where } \\
& \epsilon_{i} \sim N\left(0, \sigma_{\epsilon}^{2}\right) .
\end{aligned}
$$

The logarithm of the observed hourly wage of individual $i$ is denoted by $\log \left(W_{i}\right) . F_{i}$ is a field specific dummy which indicates whether the individual graduated in the respective field $j . L_{i}$ is a dummy for the educational level, i.e. if the individual graduated from university, university of applied science or finished vocational training. To get our field specific returns for each educational level, we include the interaction of $F_{i}$ and $L_{i}$. As described above, we use age, both in levels and squares, interacted with the dummies indicating the educational path. Thus, we allow for a flexible age-earnings-profile across, but homogeneous within the educational path. We do not interact the fields of education with the elements of the matrix $X_{i}$, i.e. person specific and demographic characteristics like tenure in the current job, nationality, regional- and year-dummies, since we assume that those have a unique effect on the wages unrelated to the field of education. Due to well-known differences in the age-earnings-profiles between men and women, we estimate the model separately rather than including gender dummies. Furthermore, we assume that the error terms follow a normal distribution.

After estimating the individual log wages, we can calculate the log hourly wages for the working population for each educational field. Since we allowed the earnings profile to vary with age in each educational path, we take this information into account by calculating the (discounted) capital value for each investment at the time of decision. Comparing the field

\footnotetext{
${ }^{5}$ There might be a bias resulting from non-random sample selection into work participation varying by field of education. We controlled for this possible selection using a standard Heckman estimation model (see Heckman, 1979). While we find that the selection term is significant, it does not affect our coefficient-estimates for the returns to educational fields. This finding is in line with Lauer and Steiner (2000). The Heckman estimation results are available upon request from the authors.
} 
specific returns at an arbitrary age might bias our measure, i.e. in younger ages the vocational educations tend to have a higher return, whereas university education pays off at a later age. Therefore, we calculate the (discounted) capital value ${ }^{6}$ at the time of high-school graduation, the time when decisions of further educations are made. This procedure allows us a more accurate comparison between the different fields of education as different durations of educational programs are adequately taken into account. To picture the problem, Figure B1 and Figure B2 in the appendix show the age-earnings profiles for the different educational levels for men and women.

For our efficiency analysis, we are interested in the average of the estimated field specific returns net of the effect of individual characteristics. Thus, we calculate the log hourly earnings as function of field specific characteristics, taking into account the age profile for the respective educational path:

$$
\begin{aligned}
\hat{R}_{j}= & \sum_{t=0}^{T_{R}} \frac{1}{\gamma^{t}}\left(\sum_{j=1}^{J} \hat{\alpha}_{0 j} F_{j}+\sum_{l=1}^{L} \hat{\alpha}_{1 l}(19+\mathrm{t}) L_{j}+\sum_{l=1}^{L} \hat{\alpha}_{2 l}(19+\mathrm{t})^{2} L_{j}\right) \\
& -\left(\sum_{t=0}^{T_{e d u_{j}}} \frac{1}{\gamma^{t}}\left(\sum_{j=1}^{J} \hat{\alpha}_{0 j} F_{j}+\sum_{l=1}^{L} \hat{\alpha}_{1 l}(19+\mathrm{t}) L_{j}+\sum_{l=1}^{L} \hat{\alpha}_{2 l}(19+\mathrm{t})^{2} L_{j}\right)\right) \\
& \text { with } \\
& \gamma: \text { Discount factor, and } \\
& T_{R}: \text { Retirement age, and } \\
& T_{e d u_{j}}: \text { Years of education for field } \mathrm{j} .
\end{aligned}
$$

The fact that some fields of education require more years to graduate than others is denoted by the substraction term. This way periods with no labor income (because the individual is still in education) are accounted with zero income. ${ }^{7}$

As we want to compare the returns of a specific field to the average returns, we calculate the average capital value of the sample returns $\bar{R}$ over all fields:

$$
\overline{\hat{R}}=\frac{1}{N} \sum_{j=1}^{J} N_{j} \hat{R}_{j} .
$$

$N_{j}$ denotes the number of all working persons in field $j$, whereas $N$ reflects the number of all working individuals in the sample.

Furthermore, we assume that an individual takes into account possible unemployment risk

\footnotetext{
${ }^{6}$ Note that this is the capital value of the logarithm of the hourly wages and not of the actual hourly wages.

${ }^{7}$ Actually, students in vocational training receive a small wage and university students are eligible for student support. We view this income as a subsistence income and do not include it in the calculation of lifetime income. Further, we neglect from any moonlighting during the course of education.
} 
when he/she forms his/her expectations about the field specific returns. We thus weight the returns with the unemployment probability in each field calculated as ratio of unemployed individuals on individuals in labor force. Thus, with the probability $r_{u e, j}=P$ (unemployed $=$ $\left.1 \mid F_{j}\right)$ a graduate in field $j$ will only receive a minimum payment $U B R$. In Germany, unemployed persons are entitled for unemployment benefit rate, i.e. Arbeitslosengeld 1, which is 63 percent (67 percent for parents) of the previous net wage in the first year of unemployment. As we only have cross-sectional data, we have no information on the duration of unemployment, but since individuals with a university entrance exam have a relative small unemployment probability it is a reasonable assumption that unemployment only occurs temporarily.

$$
E\left[\hat{R}_{j}\right]=\left(r_{u e, j} * U B R+\left(1-r_{u e, j}\right)\right) \hat{R}_{j}
$$

\subsection{Measuring the variability}

The second part of the Sharpe-ratio is an indicator for the variability of the returns. The straight forward measure is the standard deviation. With our estimation approach, we are able to split the variation in the returns into an explainable part, as well as an unexplainable part, which is the residual variation between individuals. The latter one is of interest when accounting for the variability in the returns of a specific field and will be referred to as earnings risk. ${ }^{8}$ Our variance within a specific field $j$ is thus defined as:

$$
\begin{aligned}
V A R\left[R_{j}\right]= & \sigma_{R_{j}}^{2}=\sum_{t=0}^{T_{R}} \frac{1}{\gamma^{t}} V A R\left[\epsilon_{i}\right]-\sum_{t=0}^{T_{e u_{j}}} \frac{1}{\gamma^{t}} V A R\left[\epsilon_{i}\right] \quad \forall i \in j \\
& \text { with } \\
& \epsilon_{i}=\log \left(w_{i}\right)-\widehat{\log \left(w_{i}\right)} \\
& \text { and } \\
& \gamma: \text { Discount factor, and } \\
& T_{R}: \text { Retirement age, and } \\
& T_{e d u_{j}}: \text { Years of education for field } \mathrm{j} .
\end{aligned}
$$

As we calculated the earnings as (discounted) capital value over the lifetime, we do the same with the variances. While more education leads to a shorter working period over the lifetime, the (non-existent) income while being in education is risk free. To account for different unemployment incidents across the fields, we explicitly include the unemployed individuals in our calculation of $\epsilon_{i}$ by setting their hourly wage to 63 percent of the field specific average log-wage. Thus, the higher the share of unemployed persons in a specific field, the higher the

\footnotetext{
${ }^{8}$ Strictly speaking, the error term also includes factors that are not directly interpretable as earnings risk since they might be known to the individual but unobservable for the researcher.
} 
variance in the respective field will be. ${ }^{9}$

We now have all relevant measures: The returns and their variability which allow us to evaluate the fields of education in terms of their efficiency by calculating the modified Sharperatio as:

$$
\hat{S}_{j}=\frac{E\left[\hat{R}_{j}\right]-\overline{\hat{R}}}{\hat{\sigma}_{R_{j}}} .
$$

\section{Data and descriptives}

Our empirical analysis is based on data from the German Micro Census for the years 2005 to 2009. The Micro Census is the main German labor force survey, a 1 percent representative sample of the German population. Thus, the Micro Census has the advantage of a large sample size. Starting in 2005, the survey asked each participant about his/her subject of degree as a compulsory question. ${ }^{10}$

Our sample is restricted to individuals who passed the university entrance exam, the Abitur, and finished a professional degree in either a vocational program, at a university of applied science or a university. In Germany, individuals can choose between these three options after secondary schooling. While vocational programs are open to students from all levels of secondary schooling, the university educations are open only to those who passed the university entrance examination after 13 years of schooling. ${ }^{11}$ Depending on the field of education the academic educations usually last between 4 to 6 years. Educational programs at a university of applied science are usually shorter than programs at a university. To account for different lengths of educational programs, we assign the median number of semesters needed to graduate to each field of study. ${ }^{12}$ Three years of training are usually required to obtain a vocational training certificate. Hence, we assign three years to all vocational training fields. ${ }^{13}$ Because we only

\footnotetext{
${ }^{9}$ This assumption holds as long as unemployed persons do not dominate, then the effect would reverse, e.g. with everyone being unemployed, the variance would be eliminated since everyone would get the same "wage". But the occurrence of unemployment in our sample is overall rather low since we are only observing graduates with a university entrance diploma (see Table A3 and A4).

${ }^{10}$ To answer the questions is compulsory by law. Before 2005 participants were asked about their subject of degree, but the answer was voluntary, which leads to a large share of missing values and might result in a selection bias. Before 2002 only graduates from an academic institution were asked about their subject of degree in every fourth wave of the survey.

${ }^{11}$ During the period the individuals of our sample are observed students had to attend school for 13 years (with the exception of some eastern federal states with only 12 years) and pass the university entrance examination after the 13th year of schooling to be able to choose between all three types of education. Our sample also includes students who left school after 12 years of education and are only eligible for university of applied science and vocational education but not for university education.

${ }^{12}$ The median number of semesters refer to the median number in 2003 and are taken from Wissenschaftsrat (2005b) and Wissenschaftsrat (2005a). We convert the median number of semesters to years of education by dividing by two (two terms per year).

${ }^{13}$ It is possible to shorten the vocational training time to 2 or 2,5 years for students with a university entrance certificate. Still, many students need at least 2,5 years.
} 
have individuals in our sample who finished a professional education, the youngest person in our sample is 21 years old. ${ }^{14}$

The sample is further restricted to individuals younger than the official retirement age of 65 years. There is no direct question on earnings in the German Micro Census. However, the survey asks for respondent's monthly net income. For the analysis of earnings, we restrict our sample to those who report income from own labor to be their main source of income. Because only net income is available in the data set, our measure of earnings is not free of effects the tax system has on earnings. To proximate a measure for earnings which is free of effects from the tax system, we use information on family status and employment status (part-time or full-time).

Our sample is restricted to those for whom we observe income from labor and to individuals who are unemployed. The second group, the unemployed, is included in the sample to calculate the field-specific unemployment rate and to account for the risk of unemployment when estimating the field-specific earnings risk. The Micro Census provides the information on income in 24 brackets. We calculate the mean for each bracket with data from the German-Socio-Economic Panel. Table A1 shows that the calculated means are very close to the bracket mean in all cases. In our analysis we use hourly earnings by dividing the monthly earnings by the individuals hours usually worked.

Table A2 shows the descriptives of our sample, which consists of 215,810 individuals, 126,314 men and 89,496 women. The average hourly net earnings for men are 16 Euros and 12 Euros for women. This wage differential is in line with estimates for the gender wage gap (Machin and Puhani, 2003). Men and women spent on average 17 years in education. Men have tenure at their current workplace of about 10 years and women of about 9 years. The level of unemployment in our sample is 5 percent for men and 6 percent for women. The table further describes the means of the additional control variables.

The large number of observations guarantees that we have sufficient observations even in educational fields that are less frequently chosen. ${ }^{15}$ To achieve a strong validity of our results, we restrict our analysis to fields of education in which we observe the earnings of at least 300 individuals. When restricting our sample to fields with a sufficient number of observations we have 74 fields left for our analysis. For men we observe more fields with more than 300 individuals (63 educational fields) than for women (56 educational fields).

For presentation purposes we focus on 25 fields out of the 74 fields of education when discussing our results. We selected these fields from vocational and academic education with

\footnotetext{
${ }^{14}$ School entrance age of 6 years +12 years of schooling (includes elementary and secondary education) + 3 years of vocational education.

${ }^{15}$ Another potential data source would be the German Socio Economic Panel (SOEP), which recently added information on subject of graduation additionally to the already available information on higher educational degrees. The disadvantage of this data set is the smaller sample size, which would only allow us to analyze the most popular fields of education.
} 
varying program length in order to represent the characteristics of the full range of fields in the sample. The chosen fields and their characteristics are shown in Table A3 and A4. The first column of the tables depicts the hourly earnings for men (Table A3) and women (Table A4). The average hourly earnings by field are not corrected for varying distribution of characteristics over the fields as for example different age structures and different magnitudes of forgone earnings due to more years spent in education. For this uncorrected measure of earnings the fields of dentistry (uni), medicine (uni), industrial engineering (appsc.), management science (appsc.) and finance and insurance (appsc.) rank highest for men. For women the medical fields are followed by university educations in teaching, law and business. As we will see later on, the ranking of fields changes when field specific characteristics as the length of the educational program, the unemployment probability and personal characteristics of the graduates are controlled for.

\section{Results}

The results of the field specific returns are derived from estimating a modified version of the standard Mincer wage regression as described in Section 2. Table A5 gives the coefficients of the regression. The first and third column give the estimation results for men and women. Column 5 shows the estimation results for men who graduated from an engineering field. As expected, for all fields, the hourly earnings increase with age at a diminishing rate. The effect of tenure in the current firm is significantly positive for men and women. Furthermore, German nationals tend to have higher hourly earnings and earnings tend to be lower in the eastern part of Germany. Our dependent variable is net earnings because gross earnings are not reported in the dataset. For that reason, the return and risk measure is not free of effects the tax system and social insurance has on net earnings. We include a dummy variable for being married and for working part-time (and the interaction between both) in the wage equation to catch the major tax effects. Married taxpayers in Germany can file a joint tax return which reduces the tax burden and, thus, increases net earnings. The monetary benefit of this joint tax return increases, the higher the income difference of the married couple is. As expected, being married has a positive effect on net earnings for men. For women the effect of being married is not statistically significant. Part-time work can also lead to a lower tax-rate and therefore increased net earnings. The effect of part-time on earnings is positive and significant for both sexes. For women, though, the interaction of being married and working part-time has a strong negative effect on earnings.

The excess returns $\left(E\left[\hat{R}_{j}\right]-\overline{\hat{R}}\right)^{16}$ for the selected fields are shown in Table A6 and Table A7. ${ }^{17}$ Columns 1 to 3 give the excess returns when the capital value of each field is not discounted $(\gamma=1)$. Columns 4 to 5 show the values when earnings are discounted with a rate of $\gamma=1.03$.

\footnotetext{
${ }^{16}$ Note that the excess returns for men and women are calculated with respect to the sample average for men and women respectively. The sample average for men is $\overline{\hat{R}}=45.85$, and for women $\overline{\hat{R}}=43.41$.

${ }^{17}$ Table A12 and A13 show the returns for the full set of fields.
} 
For men, the university fields of dentistry and medicine yield the highest returns over the lifecycle if earnings are not discounted. The medical fields are followed by an education in industrial engineering (appsc.), business (uni) and computer science (uni). Other than for men, teaching belongs to the "top 5" performing fields for women. The "top 5" fields for women are: Dentistry (uni), medicine (uni), management science (appsc.), teaching (uni) and finance and insurance (appsc.). Dentistry and medicine are clear outliers with an hourly wage that is almost 50 percent higher than the sample average. This result is comparable to the results of Chevalier (2011) who finds a similar pattern for the UK. At the lower end of the distribution of returns are vocational educations, both for men and women. Although graduates from a vocational program forgo fewer earnings early in their life, academic graduates catch up through higher earnings and a steeper wage increase over the life-cycle. The academic education with the lowest returns is social work (uni) for men and construction engineering for women. However, even if most of the academic fields yield comparably high returns, a university education is not in all cases preferable to vocational education in terms of returns. For example, for men an education in vocational training in business yields higher returns as a university education in political science.

If the capital value of each field is discounted to consider that individuals prefer earnings at an earlier point in time, the ranking of fields changes. In particular fields with a shorter program length, e.g. programs at a university of applied science and in vocational training, become financially more attractive. Graduating in law or computer science from a university, for example, looses rank, while a degree from a university of applied science in management science or business becomes one of the five top-performing fields for men and women.

When calculating the returns to a field of education, we do not consider costs associated with the field except for forgone earnings while in education. Since there were no tuition fees for post-secondary education in Germany for the students observed in our sample, we do not have to account for this type of cost. Still, some fields of education yield high returns mainly for those who become self-employed. As shown in Table A3 and A4, dentists, medical doctors and legal scientists have the highest share of self-employed and earnings vary widely between the self-employed and employees. For medical doctors and dentists high investment costs are associated with becoming self-employed, i.e. starting their own doctor's office. Hence, it has to be kept in mind that some of the returns to these educations will be the returns to investment into financial capital that the individual had to make earlier. The high returns for management science, teaching and finance and insurance can be assumed to be connected to the civil servant status and the low risk of unemployment of a high proportion of the graduates from these fields. To account for the special status of civil servants and self-employed, we estimate a specification of the Mincer wage regression which adjusts the returns for the employment status. Table A8 and A9 show that, as expected, the returns to management science and teaching rank lower than in the baseline specification because the specification controls for the effect the civil servant status has on earnings. 


\subsection{Mean-variance plots}

In order to evaluate the fields of education as investment goods, we depict our estimation results as mean variance plots in Figure 1 for men and Figure 2 for women. Returns and risk for each field are plotted against each other. The fields chosen for presentation are labeled. Further, fields belonging to the group of technical subjects (MINT-fields) are marked because they receive special attention in our analysis. As described above, our measures are the discounted capital values of the logarithm earnings over the life-cycle. The expected excess returns are thus defined as the deviation of the discounted capital value of log earnings for each field from the sample mean of the discounted capital value of log earnings over all fields. The sample means of the discounted capital values of log-earnings account to 45.85 Euros for men and 43.41 Euros for women. The risk measure is the standard deviation of capital value of the (log-) earnings within a field. As we conducted separate earnings regression, we also present all parameters separately for men and women.

Figure 1: Mean-Variance plot: Men

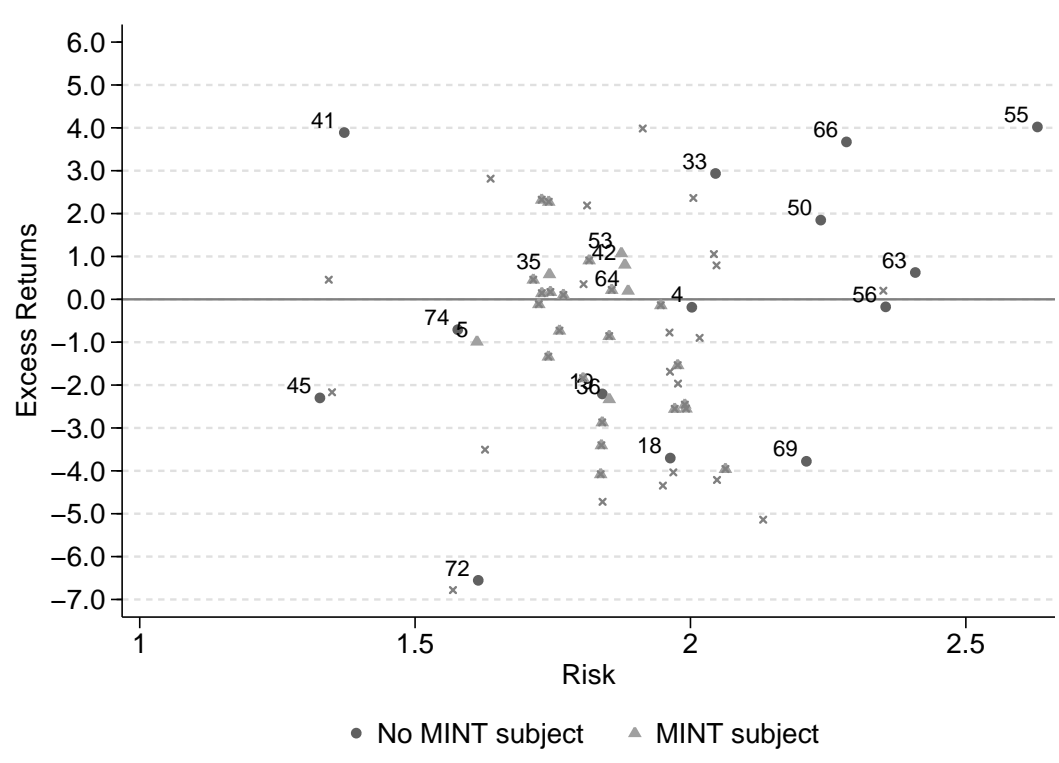

4 Voc:Business

$5 \quad$ Voc:Chemical Engineering

18 Voc:Media

19 Voc:Medical Services

33 AppSc:Business

35 AppSc:Computer Science

36 AppSc:Construction Engineering

41 AppSc:Management Science

42 AppSc:Manufacturing Engineering

45 AppSc:Social Work

50 Uni:Business

53 Uni:Computer Science

55 Uni:Dentistry

56 Uni:Economics

63 Uni:Law

64 Uni:Manufacturing Engineering

66 Uni:Medicine

69 Uni:Political Science

72 Uni:Social Work

74 Uni:Teaching

Notes: Only selected fields are labeled. The remaining fields are depicted as $x$.

In general, we find that higher levels of education are associated with higher expected returns but also with higher risk. Literature suggests that the variance of earnings is increasing with the level of schooling (see e.g. Levhari and Weiss, 1974; Hartog and Vijverberg, 2007), but this view is not straight forward (Belzil and Leonardi, 2007). Schooling may reduce earnings variation by reducing the unemployment risk or by raising the job offer probabilities but it may increase wage variation if more educated workers find jobs in sectors of occupations where wages are more volatile. Our estimates take into account the lower unemployment risk at higher education levels as explained in Section 2. Unemployment is rather low for our sample of individuals with a university entrance degree, hence the probability of unemployment does not contribute a lot 


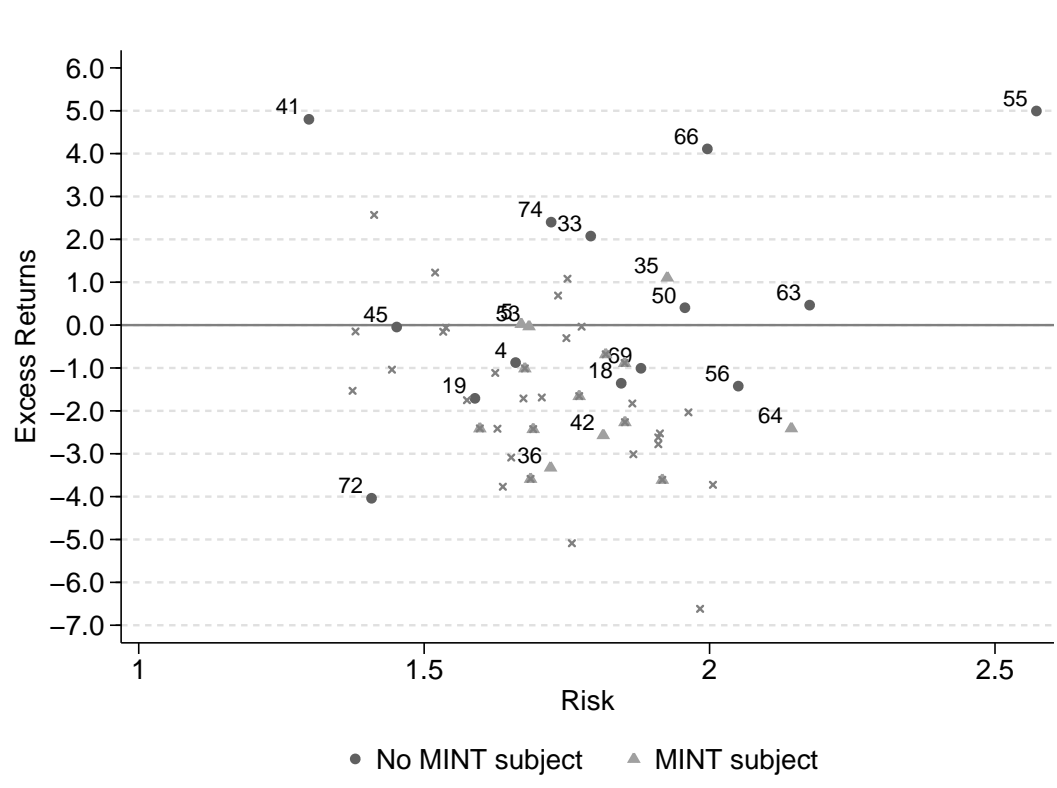

Notes: Only selected fields are labeled. The remaining fields are depicted as $x$.
Voc:Business

Voc:Chemical Engineering

Voc:Media

Voc:Medical Services

AppSc:Business

AppSc:Computer Science

AppSc:Construction Engineering

AppSc:Management Science

AppSc:Manufacturing Engineering

AppSc:Social Work

Uni:Business

Uni:Computer Science

Uni:Dentistry

Uni:Economics

Uni:Law

Uni:Manufacturing Engineering

Uni:Medicine

Uni:Political Science

Uni:Social Work

Uni:Teaching

to the earnings variation. In addition to the higher risk at higher education levels, we find that the different fields also show a high heterogeneity with respect to risk and returns within an education level, which is disregarded, when only comparing different levels of education.

The graph also shows the importance of taking risk into account. Simply comparing the returns for men for e.g. management science (appsc.) with business (appsc.) would yield no difference because the monetary return over the life-cycle is relatively close. But the average returns for business exhibit a much higher risk level, such that this field is more unattractive than management science in terms of an investment good.

Fields belonging to the group of technical fields receive special attention because of the controversially discussed shortage of graduates from these fields of education in Germany. The mean-variance plots show the efficiency of one field compared to another. Following standard economic theory of demand and supply, prices for graduates from fields with a shortage of graduates should be high, i.e. we should observe high earnings and a low level of earnings risk. Our results do not suggest that there is a shortage of skilled labor in these subjects since we do not observe high prices for graduates from technical fields compared to other fields. Other fields, especially from the group of social science fields are still more attractive investments. However, our model is not suited to predict a possible shortage in the (near) future, as we are only able to use retrospective data. 


\subsection{Technical abilities}

To reduce the role of potential ability bias, we compare the properties of human capital returns within a group of fields. Individuals who revealed a preference for a engineering field of education are likely to be similar with respect to their educational preferences and abilities. Figure 3 shows the mean-variance plot for all engineering educations for men. ${ }^{18}$ The sample average mean of the discounted capital value of log-earnings for men who graduated from a technical field is 44.88 Euro. For the technical fields risk seems to decrease with returns. On the one hand, the highest paying fields supply engineering and electrical engineering (appsc.) have a very low risk level. On the other hand, students who graduate from architecture can expect only low returns at a high level of risk. When comparing earnings within a certain group of fields, we observe that the discounted life-time log-earnings with a vocational degree are often not much lower than with a university degree. Manufacturing engineering at a university yields about the same returns over the life-cycle as a vocational degree in the same field. Further, the earnings risk is to some extend lower when graduating from vocational training. In contrast, graduating from a university of applied science with a degree in electrical engineering is preferable to a vocational training degree in the same field. Hence, university education is not always the choice with the highest investment value.

The results show that the field of education is as interesting as the level of education when assessing human capital investments. A student interested in a university of applied science education in a technical field should, for example, prefer manufacturing engineering over construction engineering because it yields a higher return at the same level of risk.

Figure 3: Mean-Variance plot: Engineering fields, Men

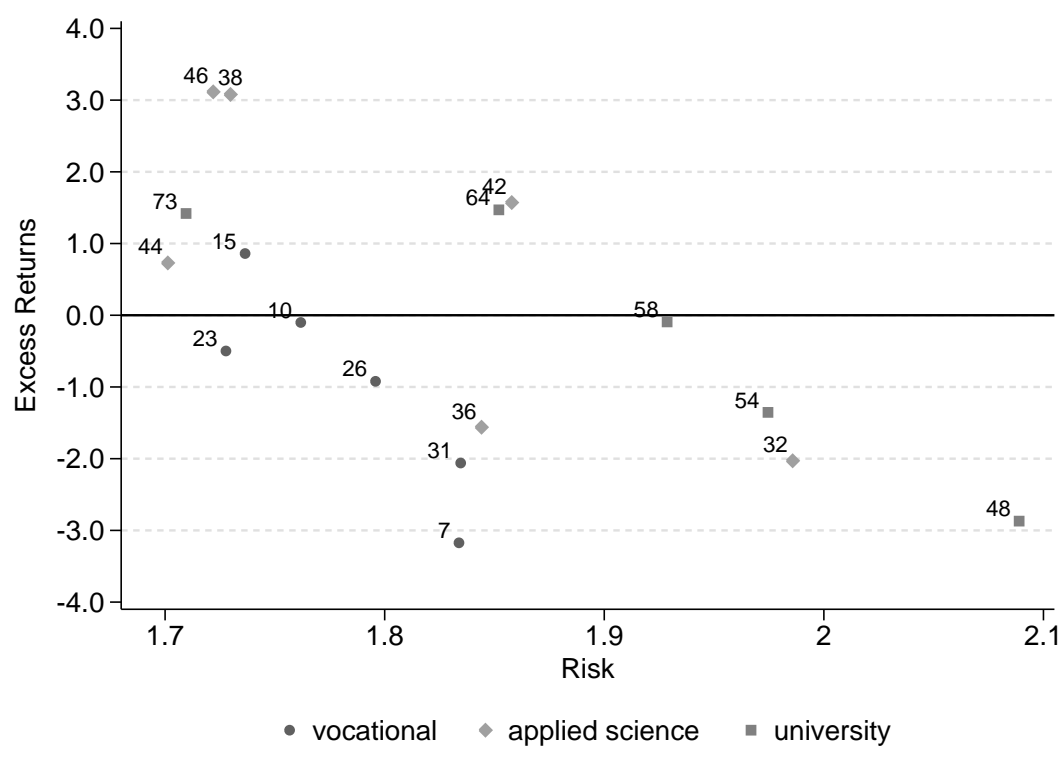

$7 \quad$ Voc:Construction Engineering

10 Voc:Electrical Engineering

15 Voc:Manufacturing Engineering

23 Voc:Precision Engineering

26 Voc:Supply Engineering

31 Voc:Transport Engineering

32 AppSc:Architecture

36 AppSc:Construction Engineering

38 AppSc:Electrical Engineering

42 AppSc:Manufacturing Engineering

44 AppSc:Precision Engineering

46 AppSc:Supply Engineering

48 Uni:Architecture

54 Uni:Construction Engineering

58 Uni:Electrical Engineering

64 Uni:Manufacturing Engineering

73 Uni:Supply Engineering

\footnotetext{
${ }^{18}$ Returns and risk measures are estimated based on a sample of 37,385 male graduates from MINTfields. Results for women are available from the authors upon request.
} 


\subsection{Standardized return measure}

In order to further assess the risk-return trade-off, we apply the standardized return measure. The standardized return measure gives us the returns per standard deviation of the unexplained part of the returns. Table A10 for men and Table A11 for women rank the educations from the highest standardized return to the lowest. As for the unstandardized returns the top-performing fields consist of programs at the university and university of applied science level. The ranking of the fields, thus, changes. Fields with a low earnings risk move up in the ranking. It is not surprising that management science performs better when earnings risk is taken into account. Around 80 percent of graduates from the field of management science are employed as civil servants. A career as a civil servant traditionally is connected to low earnings risk and low risk of unemployment. For men, social work at university and university of applied science belong to the low performing fields while for women construction engineering belongs to the worst 5 educations. Also, teaching ranks only $35^{\text {th }}$ for men, while it is one of the top-performing fields for women. Similarly, medical services is at the very bottom of the ranking for men, while it is one of the top performing vocational educations for women. ${ }^{19}$

The differences in the performance of fields between men and women might explain some of the wide differences of educational choices for men and women. As it is often discussed (see e.g. Machin and Puhani, 2003; Zafar, 2009) women are assumed to choose fields in humanities, language, education and creative arts etc., because it relates to the "traditional" female work environments. Our findings suggest that their choices can also be linked to "rational" investment choices.

\section{Conclusion}

In our paper, we analyze the risk and return properties of approximately 70 different educational fields. While there is a broad literature analyzing the returns to different educational levels, little research examines the returns to education at a more disaggregated level. Results suggest that the financial performance of different educations does not only vary across qualification levels but does also vary strongly within a qualification level. Further, the financial attractiveness of fields varies by gender.

We use the German Micro Census for the years 2005 to 2009 to estimate field specific returns by extending the Mincer wage equation controlling for different fields of education. We then use our estimation results to calculate an average measure of log hourly income over the life-cycle, as well as field specific earnings risk. Applying general models from the financial asset theory to our estimation results allows us to evaluate the fields of education in terms of their efficiency as investment goods.

\footnotetext{
${ }^{19}$ Table A12 and A13 show the standardized returns for the full set of fields.
} 
In general, higher educational levels yield higher expected returns, but are also associated with greater variance. In addition, we show that beyond the general tendency across educational levels, there is heterogeneity within educational levels that should not be neglected. In this regard, graduating in business from a university yields higher expected returns than majoring in business at a university of applied science (between educational levels), it also yields higher returns than majoring in maths at a university (within educational level). Furthermore, we show that risk is a source that should not be neglected. Even though graduates in management science (university of applied science) earn on average the same as graduates in business (university level), the latter is associated with a higher risk which makes it an inefficient investment choice over management science.

The findings are in particular helpful in terms of analyzing shortages of skilled labor in certain fields of education, as well as finding instruments to solve this possible problem. A shortage of skilled labor should be reflected in high returns and a relatively low risk associated with the education that exhibits the shortage. In Germany, a controversially-discussed topic is the shortage of skilled labor in the MINT-subjects. Our results however do not suggest that there is a shortage of skilled labor in these subjects, at least not in the time of our analysis. However, our model is not suited to predict a possible shortage in the (near) future, as we are only able to use retrospective data.

Even though we are using a rich dataset, there are several problems we could not address in our study. Thus, it remains for future studies to determine possible biases resulting from ability sorting or endogeneity of educational fields when estimating field specific returns. Another extension of our study would be to incorporate our findings into an educational decision process. But so far, there is no extensive dataset available (for Germany) that would allow us to model the field an individual chooses while controlling for the individuals socio-economic background as well as the expected returns and the associated risk. 


\section{References}

Altonji, J. G., E. Blom, and C. Meghir (2012): "Heterogeneity in Human Capital Investments: High School Curriculum, College Major, and Careers," Discussion paper, NBER Working Paper.

Ammermüller, A., And A. M. Weber (2005): "Educational Attainment and Returns to Education in Germany: An Analysis by Subject of Degree, Gender and Region," ZEW Discussion Papers 05-17, ZEW - Zentrum für Europäische Wirtschaftsforschung / Center for European Economic Research.

Anger, C., O. Koppel, And A. Plünnecke (2011): "Mint-Report 2011," Gutachten, Institut der Deutschen Wirtschaft Köln.

Arcidiacono, P. (2004): "Ability sorting and the returns to college major," Journal of Econometrics, 121(1-2), $343-375$.

Arcidiacono, P., V. J. Hotz, And S. Kang (2011): "Modeling College Major Choices using Elicited Measures of Expectations and Counterfactuals," Working Paper 15729, National Bureau of Economic Research.

BECKer, G. (1964): Human capital: A theoretical and empirical analysis, with special reference to education. University of Chicago Press, New York, 3rd edn.

Beffy, M., D. Fougre, and M. Arnaud (2012): "Choosing the Field of Study in Postsecondary Education: Do Expected Earnings Matter?," The Review of Economics and Statistics, 94(1), 334-347.

BelziL, C., AND M. LeOnARdi (2007): "Can risk aversion explain schooling attainments? Evidence from Italy," Labour Economics, 14(6), 957 - 970.

Berger, M. C. (1988): "Predicted Future Earnings and Choice of College Major," Industrial and Labor Relations Review, 41(3), pp. 418-429.

Blundell, R., L. Dearden, C. Meghir, and B. Sianesi (1999): "Human capital investment: the returns from education and training to the individual, the firm and the economy," Fiscal Studies, 20(1), 1-23.

Boudarbat, B., And C. Montmarquette (2009): "Choice of fields of study of university Canadian graduates: the role of gender and their parents' education," Education Economics, $17(2), 185-213$.

Brenke, K. (2010): "Fachkräftemangel kurzfristig noch nicht in Sicht," Wochenbericht 46, DIW Berlin. 
Carneiro, P., K. T. Hansen, and J. J. Heckman (2003): "2001 Lawrence R. Klein Lecture Estimating Distributions of Treatment Effects with an Application to the Returns to Schooling and Measurement of the Effects of Uncertainty on College Choice," International Economic Review, 44(2), 361-422.

Chevalier, A. (2011): "Subject choice and earnings of UK graduates," Economics of Education Review, 30(6), 1187 - 1201.

Christiansen, C., J. S. Joensen, And H. S. Nielsen (2007): "The risk-return trade-off in human capital investment," Labour Economics, 14(6), 971 - 986.

Cochrane, J. H. (2001): Asset Pricing. Princeton University Press.

European Comission (2010): "A strategy for smart sustainable and inclusive growth," Discussion paper, European Comission.

Fossen, F., And D. Glocker (2011): "Expected future earnings, taxation, and university enrollment," International Tax and Public Finance, 18, 688-723.

Hartog, J., And W. P. Vijverberg (2007): "On compensation for risk aversion and skewness affection in wages," Labour Economics, 14(6), 938 - 956.

Heckman, J. J. (1979): "Sample Selection Bias as a Specification Error," Econometrica, 47(1), pp. $153-161$.

Kelly, E., P. J. O'Connell, And E. Smyth (2010): "The economic returns to field of study and competencies among higher education graduates in Ireland," Economics of Education Review, 29(4), 650 - 657 .

Lauer, C., And V. Steiner (2000): "Returns to education in West Germany: an empirical assessment," ZEW Discussion Papers 00-04, ZEW - Zentrum für Europäische Wirtschaftsforschung / Center for European Economic Research.

Levhari, D., And Y. Weiss (1974): "The Effect of Risk on the Investment in Human Capital," The American Economic Review, 64(6), pp. 950-963.

Machin, S., And P. A. Puhani (2003): "Subject of degree and the gender wage differential: evidence from the UK and Germany," Economics Letters, 79(3), 393-400.

Markowitz, H. (1952): "Portfolio Selection," The Journal of Finance, 7(1), pp. 77-91.

Mincer, J. (1974): Schooling, Experience, and Earnings. Columbia University Press, New York.

Mincer, J. (1991): "Education and Unemployment," NBER Working Papers 3838, National Bureau of Economic Research, Inc. 
Oreopoulos, P., And K. G. Salvanes (2011): "Priceless: The Nonpecuniary Benefits of Schooling," Journal of Economic Perspectives, 25(1), 159-84.

Palacios-Huerta, I. (2003): "An Empirical Analysis of the Risk Properties of Human Capital Returns," The American Economic Review, 93(3), pp. 948-964.

Psacharopoulos, G., And H. A. Patrinos (2004): "Returns to investment in education: a further update," Education Economics, 12(2), 111-134.

Reinberg, A., And M. Hummel (2007): "Qualifikationsspezifische Arbeitslosigkeit im Jahr 2005 und die Einführung der Hartz-IV-Reform : empirische Befunde und methodische Probleme," IAB Forschungsbericht 200709, Institut für Arbeitsmarkt und Berufsforschung (IAB), Nürnberg.

Riddell, W. C., AND X. Song (2011): "The impact of education on unemployment incidence and re-employment success: Evidence from the U.S. labour market," Labour Economics, 18(4), $453-463$.

Sharpe, W. F. (1966): "Mutual Fund Performance," The Journal of Business, 39(1), pp. 119-138.

Wahrenburg, M., ANd M. Weldi (2007): "Return on Investment in Higher EducationEvidence for Different Subjects, Degrees and Gender in Germany," Discussion paper, Goethe University Frankfurt.

WALKer, I., AND Y. ZHU (2011): "Differences by degree: Evidence of the net financial rates of return to undergraduate study for England and Wales," Economics of Education Review, $30(6), 1177-1186$.

Willis, R. J., And S. Rosen (1979): "Education and Self-Selection," Journal of Political Economy, 87(5), S7-36.

WissenschaftsRat (2005a): "Entwicklung der Fachstudiendauer an Fachhochschulen von 1999 bis 2003," Discussion paper, Wissenschaftsrat.

(2005b): "Entwicklung der Fachstudiendauer an Universitäten von 1999 bis 2003," Discussion paper, Wissenschaftsrat.

ZAFAR, B. (2009): "College major choice and the gender gap," Staff Reports 364, Federal Reserve Bank of New York. 
Table A1: Income groups: Mean

\begin{tabular}{lc}
\hline \hline \multicolumn{1}{l}{ Income group } & Mean \\
Micro Census & SOEP \\
\hline$<150$ & $(2)$ \\
$150-300$ & 52 \\
$300-500$ & 231 \\
$500-700$ & 404 \\
$700-900$ & 620 \\
$900-1100$ & 818 \\
$1100-1300$ & 1023 \\
$1300-1500$ & 1227 \\
$1500-1700$ & 1437 \\
$1700-2000$ & 1627 \\
$2000-2300$ & 1884 \\
$2300-2600$ & 2171 \\
$2600-2900$ & 2475 \\
$2900-3200$ & 2777 \\
$3200-3600$ & 3065 \\
$3600-4000$ & 3438 \\
$4000-4500$ & 3865 \\
$4500-5000$ & 4284 \\
$5000-5500$ & 4836 \\
$5500-6000$ & 5280 \\
$6000-7500$ & 5864 \\
$7500-10000$ & 6764 \\
$10000-18000$ & 9005 \\
$>18000$ & 12886 \\
\hline Number of observations & 21778 \\
\hline \hline
\end{tabular}

Notes: The means of each income group from the Micro Census are calculated based on a sample of 15,887 individuals from the German Socio-Economic Panel. 
Table A2: Sample descriptives

\begin{tabular}{|c|c|c|c|c|}
\hline & \multicolumn{2}{|c|}{ Men } & \multicolumn{2}{|c|}{ Women } \\
\hline & Mean & Std. Dev. & Mean & Std. Dev. \\
\hline & $(1)$ & $(2)$ & $(3)$ & $(4)$ \\
\hline Net hourly earnings (Euro) & 16.43 & 11.20 & 12.29 & 7.53 \\
\hline Age (years) & 43.41 & 10.12 & 40.38 & 10.17 \\
\hline Education (years) & 17.33 & 1.52 & 17.10 & 1.50 \\
\hline Tenure (years) & 10.49 & 9.67 & 8.99 & 8.95 \\
\hline Unemployment (percent) & $4.54 \%$ & & $5.72 \%$ & \\
\hline German (percent) & $89.21 \%$ & & $88.30 \%$ & \\
\hline Married (percent) & $62.06 \%$ & & $49.73 \%$ & \\
\hline \multicolumn{5}{|l|}{ Region (percent) } \\
\hline North & $24.71 \%$ & & $23.65 \%$ & \\
\hline Middle & $35.67 \%$ & & $37.20 \%$ & \\
\hline East & $22.51 \%$ & & $19.61 \%$ & \\
\hline South & $17.11 \%$ & & $19.54 \%$ & \\
\hline \multicolumn{5}{|l|}{ Year (percent) } \\
\hline 2005 & $18.87 \%$ & & $17.82 \%$ & \\
\hline 2006 & $19.93 \%$ & & $19.47 \%$ & \\
\hline 2007 & $19.93 \%$ & & $19.64 \%$ & \\
\hline 2008 & $20.43 \%$ & & $20.92 \%$ & \\
\hline 2009 & $20.84 \%$ & & $22.15 \%$ & \\
\hline Number of observations & & 8,314 & & 496 \\
\hline
\end{tabular}

Source: Numbers based on German Micro Census, years 2005-2009.

Table A3: Characteristics: Selected fields of education, Men

\begin{tabular}{lcccccc}
\hline \hline & $\begin{array}{c}\text { Hourly } \\
\text { earnings } \\
(\text { Euro }\end{array}$ & $\begin{array}{c}\text { Share of } \\
\text { unempl. } \\
(\%)\end{array}$ & $\begin{array}{c}\text { Length of } \\
\text { education } \\
\text { (years })\end{array}$ & $\begin{array}{c}\text { Share of students } \\
\text { within degree } \\
(\%)\end{array}$ & $\begin{array}{c}\text { Share of } \\
\text { self-employed } \\
(\%)\end{array}$ & $\begin{array}{c}\text { Share of } \\
\text { civil servants } \\
(\%)\end{array}$ \\
\hline Uni:Dentistry & $(1)$ & $(2)$ & $(3)$ & $(4)$ & $(5)$ & $(6)$ \\
Uni:Medicine & 26.56 & $2.24 \%$ & 6 & $1.12 \%$ & $88.00 \%$ & $1.04 \%$ \\
Uni:Business & 23.64 & $1.30 \%$ & 6 & $5.73 \%$ & $40.42 \%$ & $3.36 \%$ \\
Uni:Law & 21.16 & $3.68 \%$ & 6 & $7.60 \%$ & $19.61 \%$ & $4.82 \%$ \\
Uni:Economics & 20.58 & $3.28 \%$ & 6 & $5.26 \%$ & $34.51 \%$ & $23.92 \%$ \\
Uni:Manufacturing Engin. & 19.67 & $5.27 \%$ & 6 & $1.69 \%$ & $19.44 \%$ & $8.26 \%$ \\
Uni:Computer Science & 18.57 & $3.19 \%$ & 6 & $3.37 \%$ & $10.23 \%$ & $5.68 \%$ \\
AppSc:Business & 17.67 & $3.49 \%$ & 6 & $2.95 \%$ & $13.36 \%$ & $2.77 \%$ \\
AppSc:Industrial Engin. & 17.43 & $3.44 \%$ & 4 & $6.31 \%$ & $16.57 \%$ & $4.49 \%$ \\
AppSc:Manufacturing Engin. & 17.41 & $3.30 \%$ & 4 & $1.28 \%$ & $10.53 \%$ & $2.22 \%$ \\
AppSc:Finance and Insurance & 17.32 & $3.76 \%$ & 5 & $4.94 \%$ & $10.82 \%$ & $2.64 \%$ \\
Uni:Teaching & 17.31 & $0.81 \%$ & 4 & $1.27 \%$ & $8.70 \%$ & $55.49 \%$ \\
AppSc:Management Science & 16.95 & $2.48 \%$ & 5 & $7.30 \%$ & $3.75 \%$ & $70.05 \%$ \\
AppSc:Computer Science & 16.59 & $0.78 \%$ & 3 & $3.98 \%$ & $1.39 \%$ & $82.69 \%$ \\
Uni:Political Science & 15.61 & $4.21 \%$ & 5 & $2.58 \%$ & $10.85 \%$ & $1.85 \%$ \\
AppSc:Construction Engin. & 15.15 & $7.32 \%$ & 6 & $0.72 \%$ & $21.27 \%$ & $8.06 \%$ \\
Voc:Business & 14.86 & $6.41 \%$ & 5 & $3.21 \%$ & $22.51 \%$ & $5.28 \%$ \\
Uni:Social Work & 13.77 & $7.50 \%$ & 3 & $7.98 \%$ & $12.85 \%$ & $1.98 \%$ \\
AppSc:Social Work & 13.62 & $7.36 \%$ & 6 & $0.45 \%$ & $9.56 \%$ & $10.38 \%$ \\
Voc:Chemical Engin. & 13.01 & $3.36 \%$ & 4 & $1.74 \%$ & $7.23 \%$ & $7.23 \%$ \\
Voc:Medical Services & 12.55 & $7.08 \%$ & 3 & $1.67 \%$ & $6.13 \%$ & $2.15 \%$ \\
Voc:Construction Engin. & 11.58 & $4.48 \%$ & 3 & $2.98 \%$ & $29.04 \%$ & $1.35 \%$ \\
Voc:Hotel Restaurant & 11.23 & $10.16 \%$ & 3 & $5.69 \%$ & $26.50 \%$ & $2.56 \%$ \\
Voc:Media & 11.19 & $13.00 \%$ & 3 & $1.60 \%$ & $18.38 \%$ & $0.55 \%$ \\
Voc:Gardening & 10.96 & $10.30 \%$ & 3 & $2.64 \%$ & $30.97 \%$ & $0.43 \%$ \\
\hline \hline
\end{tabular}

Source: Numbers based on German Micro Census, years 2005-2009. 
Table A4: Characteristics: Selected fields of education, Women

\begin{tabular}{|c|c|c|c|c|c|c|}
\hline & $\begin{array}{l}\text { Hourly } \\
\text { earnings } \\
\text { (Euro) }\end{array}$ & $\begin{array}{l}\text { Share of } \\
\text { unempl. } \\
(\%)\end{array}$ & $\begin{array}{l}\text { Length of } \\
\text { education } \\
\text { (years) }\end{array}$ & $\begin{array}{c}\text { Share of students } \\
\text { within degree } \\
(\%)\end{array}$ & $\begin{array}{c}\text { Share of } \\
\text { self-employed } \\
(\%)\end{array}$ & $\begin{array}{c}\text { Share of } \\
\text { civil servants } \\
(\%)\end{array}$ \\
\hline & $(1)$ & $(2)$ & $(3)$ & $(4)$ & $(5)$ & $(6)$ \\
\hline Uni:Dentistry & 20.65 & $3.94 \%$ & 6 & $1.33 \%$ & $77.69 \%$ & $0.61 \%$ \\
\hline Uni:Medicine & 17.70 & $4.33 \%$ & 6 & $7.24 \%$ & $31.38 \%$ & $2.36 \%$ \\
\hline Uni:Teaching & 15.18 & $2.60 \%$ & 5 & $22.47 \%$ & $2.59 \%$ & $68.48 \%$ \\
\hline Uni:Law & 15.09 & $5.22 \%$ & 6 & $5.51 \%$ & $22.67 \%$ & $25.84 \%$ \\
\hline Uni:Business & 14.00 & $6.33 \%$ & 6 & $6.61 \%$ & $10.18 \%$ & $4.15 \%$ \\
\hline Uni:Economics & 13.73 & $7.69 \%$ & 6 & $1.70 \%$ & $10.95 \%$ & $6.84 \%$ \\
\hline AppSc:Computer Science & 13.58 & $10.05 \%$ & 5 & $0.76 \%$ & $5.43 \%$ & $0.86 \%$ \\
\hline Uni:Computer Science & 13.28 & $5.37 \%$ & 6 & $0.83 \%$ & $8.40 \%$ & $2.47 \%$ \\
\hline AppSc:Management Science & 13.25 & $1.05 \%$ & 3 & $4.82 \%$ & $0.65 \%$ & $76.81 \%$ \\
\hline Uni:Manufacturing Engin. & 13.23 & $7.08 \%$ & 6 & $0.69 \%$ & $8.23 \%$ & $3.66 \%$ \\
\hline AppSc:Finance and Insurance & 13.03 & $1.09 \%$ & 4 & $1.43 \%$ & $3.17 \%$ & $60.33 \%$ \\
\hline Uni:Political Science & 13.02 & $9.78 \%$ & 6 & $0.72 \%$ & $15.62 \%$ & $6.01 \%$ \\
\hline AppSc:Business & 12.34 & $5.07 \%$ & 4 & $7.30 \%$ & $7.66 \%$ & $3.96 \%$ \\
\hline AppSc:Social Work & 11.65 & $4.85 \%$ & 4 & $6.22 \%$ & $6.53 \%$ & $5.68 \%$ \\
\hline Uni:Social Work & 11.47 & $7.18 \%$ & 6 & $1.79 \%$ & $7.14 \%$ & $6.21 \%$ \\
\hline AppSc:Manufacturing Engin. & 11.11 & $9.92 \%$ & 5 & $0.76 \%$ & $9.60 \%$ & $1.98 \%$ \\
\hline AppSc:Construction Engin. & 10.90 & $12.34 \%$ & 5 & $1.37 \%$ & $11.65 \%$ & $5.66 \%$ \\
\hline Voc:Chemical Engin. & 10.55 & $6.33 \%$ & 3 & $1.62 \%$ & $4.33 \%$ & $0.87 \%$ \\
\hline Voc:Personal Services & 10.25 & $10.77 \%$ & 3 & $0.95 \%$ & $8.31 \%$ & $9.85 \%$ \\
\hline Voc:Business & 10.06 & $8.69 \%$ & 3 & $12.90 \%$ & $5.66 \%$ & $0.91 \%$ \\
\hline Voc:Media & 9.98 & $10.29 \%$ & 3 & $1.96 \%$ & $20.30 \%$ & $0.30 \%$ \\
\hline Voc:Medical Services & 9.57 & $5.92 \%$ & 3 & $12.02 \%$ & $11.89 \%$ & $0.53 \%$ \\
\hline Voc:Textile & 8.99 & $14.72 \%$ & 3 & $0.94 \%$ & $17.48 \%$ & $1.29 \%$ \\
\hline Voc:Dentistry & 8.72 & $6.46 \%$ & 3 & $1.26 \%$ & $7.32 \%$ & $0.22 \%$ \\
\hline Voc:Beauty & 8.00 & $13.12 \%$ & 3 & $1.22 \%$ & $32.59 \%$ & $0.49 \%$ \\
\hline
\end{tabular}

Source: Numbers based on German Micro Census, years 2005-2009. 
Table A5: Mincer wage regression: Men, Women and technical fields

\begin{tabular}{|c|c|c|c|c|c|c|}
\hline & \multicolumn{2}{|c|}{ Men } & \multicolumn{2}{|c|}{ Women } & \multicolumn{2}{|c|}{ Technical fields (men) } \\
\hline & Coeff. & S.E. & Coeff. & S.E. & Coeff. & S.E. \\
\hline & (1) & $(2)$ & $(3)$ & $(4)$ & $(5)$ & $(6)$ \\
\hline Age X Voc. Educ. & $0.04^{* *}$ & 0.003 & $0.044^{* *}$ & 0.004 & $0.044^{* *}$ & 0.002 \\
\hline Age X Uni. of AppSc. & $0.047^{* *}$ & 0.003 & $0.040^{* *}$ & 0.005 & $0.044^{* *}$ & 0.010 \\
\hline Age X University & $0.070^{* *}$ & 0.006 & $0.068^{* *}$ & 0.007 & $0.061^{* *}$ & 0.006 \\
\hline $\operatorname{Age}^{2} \mathrm{Xvoc}$ & $-0.000^{* *}$ & 0.000 & $-0.000^{* *}$ & 0.000 & $-0.000^{* *}$ & 0.000 \\
\hline Age $^{2}$ Xappsc & $-0.001^{* *}$ & 0.000 & $-0.000^{* *}$ & 0.000 & $-0.001^{* *}$ & 0.000 \\
\hline $\operatorname{Age}^{2}$ Xuni & $-0.001^{* *}$ & 0.000 & $-0.001^{* *}$ & 0.000 & $-0.001^{* *}$ & 0.000 \\
\hline German & $0.121^{* *}$ & 0.010 & $0.112^{* *}$ & 0.017 & $0.140^{* *}$ & 0.011 \\
\hline Married & $0.210^{* *}$ & 0.005 & 0.006 & 0.006 & $0.192^{* *}$ & 0.007 \\
\hline Part-time work & $0.117^{* *}$ & 0.024 & $0.236^{* *}$ & 0.020 & -0.009 & 0.034 \\
\hline Married X Part-time & $-0.036 *$ & 0.018 & $-0.194^{* *}$ & 0.015 & -0.031 & 0.027 \\
\hline Tenure & $0.013^{* *}$ & 0.001 & $0.015^{* *}$ & 0.001 & $0.014^{* *}$ & 0.001 \\
\hline Tenure $^{2}$ & $-0.000^{* *}$ & 0.000 & $-0.000^{* *}$ & 0.000 & $-0.000^{* *}$ & 0.000 \\
\hline \multicolumn{7}{|c|}{ University of Applied Science: } \\
\hline Architecture & $1.171^{* *}$ & 0.072 & $1.263^{* *}$ & 0.091 & $1.258^{* *}$ & 0.067 \\
\hline Business & $1.348^{* *}$ & 0.070 & $1.379^{* *}$ & 0.090 & . & . \\
\hline Chemical Engin. & $1.344^{* *}$ & 0.071 & . & . & . & . \\
\hline Computer Science & $1.330^{* *}$ & 0.068 & $1.462^{* *}$ & 0.091 & . & . \\
\hline Construction Engin. & $1.202^{* *}$ & 0.073 & $1.252^{* *}$ & 0.088 & $1.300^{* *}$ & 0.068 \\
\hline Educational Science & . & . & $1.232^{* *}$ & 0.085 & . & . \\
\hline Electrical Engin. & $1.326^{* *}$ & 0.072 & . & . & $1.415^{* *}$ & 0.067 \\
\hline Finance and Insurance & $1.319^{* *}$ & 0.070 & $1.370^{* *}$ & 0.088 & . & . \\
\hline Industrial Engin. & $1.397^{* *}$ & 0.069 & . & . & . & . \\
\hline Management Science & $1.282^{* *}$ & 0.070 & $1.388^{* *}$ & 0.089 & $\cdot$ & . \\
\hline Manufacturing Engin. & $1.338^{* *}$ & 0.072 & $1.272^{* *}$ & 0.089 & $1.430^{* *}$ & 0.067 \\
\hline Maths & $1.275^{* *}$ & 0.072 & $1.283^{* *}$ & 0.088 & . & . \\
\hline Precision Engin. & $1.303^{* *}$ & 0.072 & . & . & $1.396^{* *}$ & 0.068 \\
\hline Social Work & $1.096^{* *}$ & 0.073 & $1.274^{* *}$ & 0.087 & . & . \\
\hline Supply Engin. & $1.327^{* *}$ & 0.072 & $\cdot$ & . & $1.415^{* *}$ & 0.067 \\
\hline \multicolumn{7}{|l|}{ University } \\
\hline Anglistic & $0.685^{* *}$ & 0.143 & $0.681^{* *}$ & 0.155 & . & . \\
\hline Architecture & $0.592^{* *}$ & 0.145 & $0.625^{* *}$ & 0.153 & $1.264^{* *}$ & 0.180 \\
\hline Biology & $0.664^{* *}$ & 0.142 & $0.706^{* *}$ & 0.153 & . & . \\
\hline Business & $0.875^{* *}$ & 0.141 & $0.805^{* *}$ & 0.151 & . & . \\
\hline Chemical Engin. & $0.746^{* *}$ & 0.145 & $0.717^{* *}$ & 0.155 & . & . \\
\hline Chemistry & $0.800^{* *}$ & 0.145 & $0.752^{* *}$ & 0.156 & . & . \\
\hline Computer Science & $0.833^{* *}$ & 0.138 & $0.774^{* *}$ & 0.154 & . & . \\
\hline Construction Engin. & $0.660^{* *}$ & 0.144 & $0.626^{* *}$ & 0.155 & $1.335^{* *}$ & 0.180 \\
\hline Dentistry & $0.975^{* *}$ & 0.146 & $1.025^{* *}$ & 0.155 & . & . \\
\hline Economics & $0.783^{* *}$ & 0.145 & $0.720^{* *}$ & 0.157 & . & . \\
\hline Educational Science & $0.594^{* *}$ & 0.147 & $0.680^{* *}$ & 0.157 & . & . \\
\hline Electrical Engin. & $0.712^{* *}$ & 0.145 & . & . & $1.391^{* *}$ & 0.179 \\
\hline Geo Science & $0.616^{* *}$ & 0.144 & $0.670^{* *}$ & 0.153 & . & . \\
\hline German Literature & $0.577^{* *}$ & 0.146 & $0.683^{* *}$ & 0.155 & . & . \\
\hline History & $0.585^{* *}$ & 0.144 & $0.679^{* *}$ & 0.155 & . & . \\
\hline Industrial Engin. & $0.840^{* *}$ & 0.141 & $\cdot$ & . & . & . \\
\hline Law & $0.807^{* *}$ & 0.143 & $0.798^{* *}$ & 0.153 & . & . \\
\hline Manufacturing Engin. & $0.784^{* *}$ & 0.144 & $0.662^{* *}$ & 0.157 & $1.457^{* *}$ & 0.181 \\
\hline Maths & $0.774^{* *}$ & 0.145 & $0.755^{* *}$ & 0.156 & $\cdot$ & . \\
\hline Medicine & $0.947^{* *}$ & 0.145 & $0.982^{* *}$ & 0.155 & . & . \\
\hline Music & $0.519^{* *}$ & 0.145 & $0.586^{* *}$ & 0.156 & . & . \\
\hline Physics & $0.796^{* *}$ & 0.144 & . & . & . & . \\
\hline
\end{tabular}




\begin{tabular}{|c|c|c|c|c|c|c|}
\hline & \multicolumn{2}{|l|}{ Men } & \multicolumn{2}{|c|}{ Women } & \multicolumn{2}{|c|}{ Technical fields (men) } \\
\hline & Coeff. & S.E. & Coeff. & S.E. & Coeff. & S.E. \\
\hline & $(1)$ & $(2)$ & $(3)$ & $(4)$ & $(5)$ & $(6)$ \\
\hline Political Science & $0.611^{* *}$ & 0.142 & $0.760^{* *}$ & 0.151 & . & . \\
\hline Psychology & $0.735^{* *}$ & 0.146 & $0.785^{* *}$ & 0.155 & . & . \\
\hline Regional Science & $0.586^{* *}$ & 0.145 & $0.653^{* *}$ & 0.154 & . & . \\
\hline Social Work & $0.464^{* *}$ & 0.147 & $0.576^{* *}$ & 0.156 & . & . \\
\hline Supply Engin. & $0.784^{* *}$ & 0.144 & . & . & $1.453^{* *}$ & 0.182 \\
\hline Teaching & $0.645^{* *}$ & 0.147 & $0.788^{* *}$ & 0.156 & . & . \\
\hline \multicolumn{7}{|l|}{ Vocational Education } \\
\hline Accounting & $1.196^{* *}$ & 0.070 & $1.117^{* *}$ & 0.059 & . & . \\
\hline Anglistic & . & . & $1.196^{* *}$ & 0.061 & . & . \\
\hline Beauty & . & . & $0.871^{* *}$ & 0.059 & . & . \\
\hline Business & $1.170^{* *}$ & 0.070 & $1.111^{* *}$ & 0.060 & . & . \\
\hline Chemical Engin. & $1.129^{* *}$ & 0.070 & $1.135^{* *}$ & 0.060 & . & . \\
\hline Computer Science & $1.202^{* *}$ & 0.067 & . & . & . & . \\
\hline Construction Engin. & $1.008^{* *}$ & 0.071 & . & . & $1.155^{* *}$ & 0.097 \\
\hline Dentistry & . & . & $0.959^{* *}$ & 0.060 & . & . \\
\hline Educational Science & . & . & $1.059^{* *}$ & 0.059 & . & . \\
\hline Electrical Engin. & $1.130^{* *}$ & 0.070 & . & . & $1.264^{* *}$ & 0.097 \\
\hline Finance and Insurance & $1.246^{* *}$ & 0.069 & $1.171^{* *}$ & 0.059 & . & . \\
\hline Gardening & $0.865^{* *}$ & 0.071 & . & . & . & . \\
\hline Hotel Restaurant & $1.023^{* *}$ & 0.070 & $1.027^{* *}$ & 0.060 & . & . \\
\hline Management Science & $1.177^{* *}$ & 0.069 & $1.123^{* *}$ & 0.059 & . & . \\
\hline Manufacturing Engin. & $1.170^{* *}$ & 0.071 & $1.111^{* *}$ & 0.061 & $1.314^{* *}$ & 0.097 \\
\hline Marketing & . & . & $1.164^{* *}$ & 0.060 & . & . \\
\hline Maths & $1.286^{* *}$ & 0.071 & . & . & . & . \\
\hline Media & $1.027^{* *}$ & 0.069 & $1.101^{* *}$ & 0.060 & . & . \\
\hline Medical Services & $1.052^{* *}$ & 0.070 & $1.051^{* *}$ & 0.058 & . & . \\
\hline Nursing & $1.054^{* *}$ & 0.071 & $1.111^{* *}$ & 0.059 & . & . \\
\hline Office Assistant & . & . & $1.040^{* *}$ & 0.059 & . & . \\
\hline Personal Services & . & . & $1.026^{* *}$ & 0.060 & . & . \\
\hline Precision Engin. & $1.108^{* *}$ & 0.071 & . & . & $1.253^{* *}$ & 0.097 \\
\hline Public Security & $1.165^{* *}$ & 0.070 & . & . & . & . \\
\hline Social Work & . & . & $1.094^{* *}$ & 0.059 & . & . \\
\hline Supply Engin. & $1.080^{* *}$ & 0.071 & . & . & $1.228^{* *}$ & 0.097 \\
\hline Textile & . & . & $0.955^{* *}$ & 0.062 & . & . \\
\hline Tourism & . & . & $1.057^{* *}$ & 0.059 & . & . \\
\hline Trade and Logistic & $1.102^{* *}$ & 0.069 & $1.065^{* *}$ & 0.059 & . & . \\
\hline Transport & $1.181^{* *}$ & 0.070 & $1.136^{* *}$ & 0.060 & . & . \\
\hline Transport Engin. & $1.051^{* *}$ & 0.071 & . & . & $1.194^{* *}$ & 0.097 \\
\hline Year dummies & \multicolumn{2}{|l|}{ yes } & \multicolumn{2}{|l|}{ yes } & \multicolumn{2}{|l|}{ yes } \\
\hline Region dummies & \multicolumn{2}{|c|}{ yes } & \multicolumn{2}{|l|}{ yes } & \multicolumn{2}{|l|}{ yes } \\
\hline $\mathrm{N}$ & \multicolumn{2}{|c|}{120,441} & \multicolumn{2}{|c|}{84,261} & \multicolumn{2}{|l|}{39,522} \\
\hline $\begin{array}{l}\text { S.E. calculated using the } \\
\text { Source: Estimation basec }\end{array}$ & $\begin{array}{l}\text { a method. } \\
\text { German M }\end{array}$ & $\begin{array}{l}\text { Census } \\
\text { Cificance }\end{array}$ & $\begin{array}{l}\text { ls: } \quad \dagger: 10 \% \\
\text { rs } 2005-2009\end{array}$ & $*: 5 \%$ & $* *: 1 \%$ & \\
\hline
\end{tabular}


Table A6: Returns to field of education: Men

\begin{tabular}{|c|c|c|c|c|c|c|}
\hline & \multicolumn{3}{|c|}{$\gamma=1$} & \multicolumn{3}{|c|}{$\gamma=1.03$} \\
\hline & Rank & $\begin{array}{c}\text { Return } \\
E\left[\hat{R}_{j}\right]-\overline{\hat{R}}\end{array}$ & S.E. & Rank & $\begin{array}{l}\text { Return } \\
E\left[\hat{R}_{j}\right]-\overline{\hat{R}}\end{array}$ & S.E. \\
\hline & $(1)$ & $(2)$ & $(3)$ & $(4)$ & $(5)$ & $(6)$ \\
\hline Uni:Dentistry & 1 & $10.941^{* *}$ & 0.609 & 1 & $4.020^{* *}$ & 0.337 \\
\hline Uni:Medicine & 2 & $10.226^{* *}$ & 0.552 & 4 & $3.672^{* *}$ & 0.313 \\
\hline AppSc:Industrial Engin. & 3 & $6.600^{* *}$ & 0.646 & 2 & $3.984^{* *}$ & 0.269 \\
\hline Uni:Business & 4 & $6.447^{* *}$ & 0.519 & 11 & $1.848^{* *}$ & 0.265 \\
\hline Uni:Computer Science & 5 & $4.854^{* *}$ & 0.504 & 12 & $1.077^{* *}$ & 0.234 \\
\hline AppSc:Management Science & 7 & $4.804^{* *}$ & 0.687 & 3 & $3.890^{* *}$ & 0.308 \\
\hline AppSc:Business & 8 & $4.509^{* *}$ & 0.629 & 5 & $2.936^{* *}$ & 0.268 \\
\hline AppSc:Finance and Insurance & 9 & $4.272^{* *}$ & 0.685 & 6 & $2.815^{* *}$ & 0.298 \\
\hline Uni:Law & 10 & $3.924^{* *}$ & 0.563 & 17 & $0.626^{* *}$ & 0.302 \\
\hline Uni:Manufacturing Engin. & 14 & $3.045^{* *}$ & 0.529 & 24 & 0.201 & 0.294 \\
\hline Uni:Economics & 18 & $2.260^{* *}$ & 0.567 & 30 & -0.175 & 0.315 \\
\hline AppSc:Manufacturing Engin. & 21 & $1.810^{* *}$ & 0.528 & 15 & $0.809^{* *}$ & 0.239 \\
\hline AppSc:Computer Science & 23 & 1.357 & 0.700 & 18 & $0.586^{\dagger}$ & 0.281 \\
\hline Uni:Teaching & 27 & -0.252 & 0.721 & 32 & -0.708 & 0.407 \\
\hline Voc:Business & 39 & $-3.052^{* *}$ & 0.647 & 31 & -0.185 & 0.286 \\
\hline AppSc:Construction Engin. & 42 & $-4.562^{* *}$ & 0.521 & 46 & $-2.328^{* *}$ & 0.245 \\
\hline Voc:Chemical Engin. & 44 & $-4.621^{* *}$ & 0.659 & 37 & $-0.986^{* *}$ & 0.292 \\
\hline Uni:Political Science & 46 & $-5.192^{* *}$ & 0.529 & 54 & $-3.777^{* *}$ & 0.280 \\
\hline AppSc:Social Work & 50 & $-5.931^{* *}$ & 0.682 & 45 & $-2.299^{* *}$ & 0.325 \\
\hline Voc:Medical Services & 55 & $-7.003^{* *}$ & 0.697 & 44 & $-2.205^{* *}$ & 0.316 \\
\hline Voc:Media & 59 & $-9.951^{* *}$ & 0.671 & 53 & $-3.702^{* *}$ & 0.297 \\
\hline Voc:Construction Engin. & 60 & $-10.690^{* *}$ & 0.567 & 57 & $-4.079^{* *}$ & 0.259 \\
\hline Uni:Social Work & 61 & $-10.929^{* *}$ & 0.697 & 62 & $-6.554^{* *}$ & 0.374 \\
\hline Voc:Hotel Restaurant & 62 & $-10.957^{* *}$ & 0.561 & 58 & $-4.212^{* *}$ & 0.242 \\
\hline Voc:Gardening & 63 & $-15.977^{* *}$ & 0.633 & 63 & $-6.781^{* *}$ & 0.287 \\
\hline Total number of Fields & 63 & & & 63 & & \\
\hline
\end{tabular}

S.E. calculated using the delta method. Significance levels: $\quad \dagger: 10 \% \quad *: 5 \% \quad * *: 1 \%$

Source: Estimation based on German Micro Census, years 2005-2009.

Notes: Columns 1 to 3 give the excess returns when the capital value of each field is not discounted $(\gamma=1)$. Columns 4 to 5 show the values when log-earnings are discounted with a rate of $\gamma=1.03$. Only selected fields are depicted. A full list of field is given in A12. 
Table A7: Returns to field of education: Women

\begin{tabular}{|c|c|c|c|c|c|c|}
\hline & \multicolumn{3}{|c|}{$\gamma=1$} & \multicolumn{3}{|c|}{$\gamma=1.03$} \\
\hline & Rank & $\begin{array}{c}\text { Return } \\
E\left[\hat{R}_{j}\right]-\overline{\hat{R}}\end{array}$ & S.E. & Rank & $\begin{array}{l}\text { Return } \\
E\left[\hat{R}_{j}\right]-\overline{\hat{R}}\end{array}$ & S.E. \\
\hline & (1) & $(2)$ & $(3)$ & (4) & $(5)$ & (6) \\
\hline Uni:Dentistry & 1 & $13.206^{* *}$ & 0.842 & 1 & $4.994^{* *}$ & 0.408 \\
\hline Uni:Medicine & 2 & $11.377^{* *}$ & 0.858 & 3 & $4.110^{* *}$ & 0.413 \\
\hline AppSc:Management Science & 3 & $7.220^{* *}$ & 1.195 & 2 & $4.800^{* *}$ & 0.560 \\
\hline Uni:Teaching & 4 & $6.370^{* *}$ & 1.102 & 5 & $2.401^{* *}$ & 0.540 \\
\hline AppSc:Finance and Insurance & 5 & $4.366^{* *}$ & 1.184 & 4 & $2.570^{* *}$ & 0.548 \\
\hline Uni:Law & 6 & $3.846^{* *}$ & 0.932 & 11 & 0.466 & 0.436 \\
\hline Uni:Business & 7 & $3.718^{* *}$ & 0.867 & 12 & 0.405 & 0.402 \\
\hline AppSc:Business & 8 & $3.380^{* *}$ & 0.981 & 6 & $2.076^{* *}$ & 0.439 \\
\hline AppSc:Computer Science & 9 & $2.950^{* *}$ & 0.885 & 8 & $1.108^{*}$ & 0.387 \\
\hline Uni:Computer Science & 10 & $2.824^{* *}$ & 0.855 & 14 & -0.028 & 0.404 \\
\hline Uni:Political Science & 14 & 0.791 & 0.853 & 24 & $-1.007^{\dagger}$ & 0.397 \\
\hline Uni:Economics & 16 & -0.063 & 0.867 & 29 & $-1.423^{* *}$ & 0.423 \\
\hline AppSc:Social Work & 21 & -0.850 & 1.096 & 16 & -0.045 & 0.522 \\
\hline Uni:Manufacturing Engin. & 25 & $-2.096^{\dagger}$ & 0.816 & 39 & $-2.407^{* *}$ & 0.401 \\
\hline Voc:Chemical Engin. & 27 & $-2.142^{\dagger}$ & 0.961 & 13 & 0.027 & 0.478 \\
\hline Voc:Business & 35 & $-3.908^{* *}$ & 0.960 & 22 & -0.874 & 0.476 \\
\hline AppSc:Manufacturing Engin. & 40 & $-4.511^{* *}$ & 0.762 & 44 & $-2.567^{* *}$ & 0.357 \\
\hline Voc:Media & 44 & $-4.855^{* *}$ & 0.935 & 28 & $-1.357^{*}$ & 0.464 \\
\hline Uni:Social Work & 46 & $-5.465^{* *}$ & 1.091 & 54 & $-4.038^{* *}$ & 0.522 \\
\hline Voc:Medical Services & 47 & $-5.540^{* *}$ & 1.082 & 33 & $-1.708^{*}$ & 0.541 \\
\hline AppSc:Construction Engin. & 50 & $-6.047^{* *}$ & 0.807 & 49 & $-3.323^{* *}$ & 0.382 \\
\hline Voc:Hotel Restaurant & 52 & $-7.639^{* *}$ & 0.890 & 46 & $-2.778^{* *}$ & 0.441 \\
\hline Voc:Personal Services & 53 & $-8.099^{* *}$ & 1.056 & 47 & $-3.012^{* *}$ & 0.531 \\
\hline Voc:Dentistry & 54 & $-9.579^{* *}$ & 1.002 & 53 & $-3.769^{* *}$ & 0.499 \\
\hline Voc:Textile & 55 & $-12.167^{* *}$ & 0.837 & 55 & $-5.087^{* *}$ & 0.416 \\
\hline Voc:Beauty & 56 & $-15.164^{* *}$ & 0.924 & 56 & $-6.617^{* *}$ & 0.459 \\
\hline Total number of Fields & 56 & & & 56 & & \\
\hline
\end{tabular}

S.E. calculated using the delta method. Significance levels: $\dagger: 10 \% \quad *: 5 \% \quad * *: 1 \%$

Source: Estimation based on German Micro Census, years 2005-2009.

Notes: Columns 1 to 3 give the excess returns when the capital value of each field is not discounted $(\gamma=1)$. Columns 4 to 5 show the values when log-earnings are discounted with a rate of $\gamma=1.03$. Only selected fields are depicted. A full list of field is given in A13. 
Table A8: Returns to field of education: Controlling for work-status, Men

\begin{tabular}{|c|c|c|c|}
\hline & Rank & $\begin{array}{l}\text { Return } \\
E\left[\hat{R}_{j}\right]-\overline{\hat{R}}\end{array}$ & S.E. \\
\hline & $(1)$ & $(2)$ & $(3)$ \\
\hline Uni:Dentistry & 1 & $5.244^{* *}$ & 0.365 \\
\hline Uni:Medicine & 2 & $4.141^{* *}$ & 0.314 \\
\hline AppSc:Industrial Engin. & 3 & $4.128^{* *}$ & 0.244 \\
\hline AppSc:Business & 4 & $3.140^{* *}$ & 0.243 \\
\hline Voc:Maths & 5 & $2.484^{* *}$ & 0.241 \\
\hline AppSc:Management Science & 8 & $2.296^{* *}$ & 0.518 \\
\hline Uni:Business & 10 & $2.023^{* *}$ & 0.251 \\
\hline AppSc:Finance and Insurance & 11 & $1.955^{* *}$ & 0.397 \\
\hline Uni:Computer Science & 12 & $1.200^{* *}$ & 0.211 \\
\hline AppSc:Manufacturing Engin. & 16 & $0.933^{*}$ & 0.216 \\
\hline AppSc:Computer Science & 17 & $0.744^{*}$ & 0.259 \\
\hline Uni:Law & 18 & $0.655^{\dagger}$ & 0.323 \\
\hline Voc:Business & 26 & 0.024 & 0.255 \\
\hline Uni:Economics & 29 & -0.089 & 0.311 \\
\hline Voc:Chemical Engin. & 34 & $-0.880^{* *}$ & 0.264 \\
\hline Voc:Medical Services & 41 & $-1.779^{* *}$ & 0.276 \\
\hline Uni:Teaching & 42 & $-2.004^{* *}$ & 0.558 \\
\hline AppSc:Construction Engin. & 43 & $-2.110^{* *}$ & 0.228 \\
\hline AppSc:Social Work & 47 & $-2.343^{* *}$ & 0.301 \\
\hline Uni:Political Science & 54 & $-3.683^{* *}$ & 0.274 \\
\hline Uni:German Literature & 59 & $-4.377^{* *}$ & 0.383 \\
\hline Uni:Music & 60 & $-4.854^{* *}$ & 0.344 \\
\hline Uni:History & 61 & $-4.897^{* *}$ & 0.327 \\
\hline Voc:Gardening & 62 & $-6.301^{* *}$ & 0.252 \\
\hline Uni:Social Work & 63 & $-6.653^{* *}$ & 0.372 \\
\hline
\end{tabular}

S.E. calculated using the delta method. Significance levels: $\quad \dagger: 10 \% \quad *: 5 \% \quad * *: 1 \%$ Source: Estimation based on German Micro Census, years 2005-2009

Notes: Excess returns are calculated using a discount rate of $(\gamma=1.03)$. The additional control variables in the wage equation are indicator variables for self-employment and civil service status. Only selected fields are depicted. 
Table A9: Returns to field of education: Controlling for work-status, Women

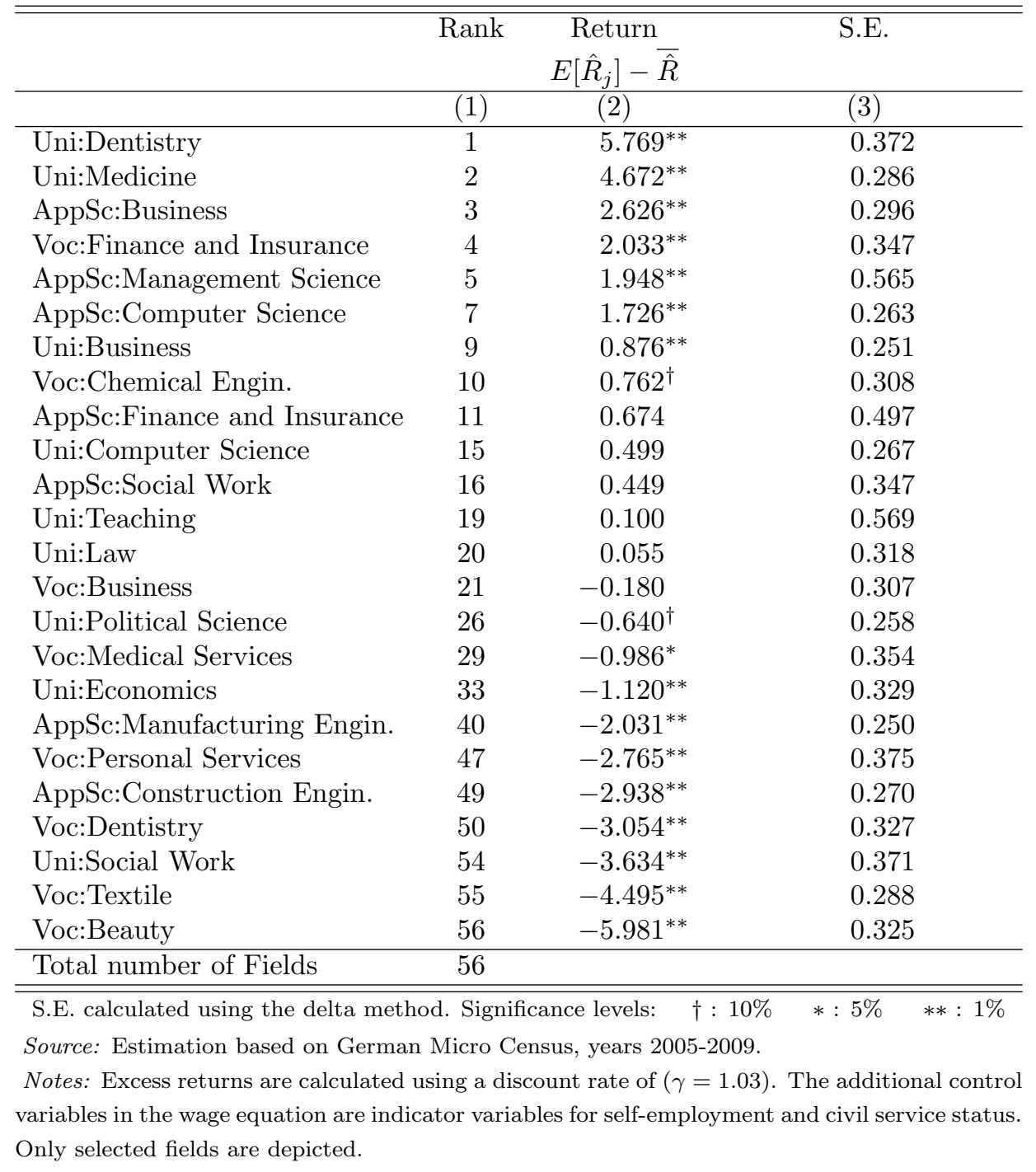


Table A10: Standardized Returns, Men

\begin{tabular}{|c|c|c|c|}
\hline & Rank & $\begin{array}{c}\text { Standardized } \\
\text { Return } \\
S j\end{array}$ & S.E. \\
\hline & $(1)$ & $(2)$ & $(3)$ \\
\hline AppSc:Management Science & 1 & $2.836^{* *}$ & 0.225 \\
\hline AppSc:Industrial Engin. & 2 & $2.082^{* *}$ & 0.140 \\
\hline AppSc:Finance and Insurance & 3 & $1.719^{* *}$ & 0.182 \\
\hline Uni:Medicine & 4 & $1.608^{* *}$ & 0.137 \\
\hline Uni:Dentistry & 5 & $1.529^{* *}$ & 0.128 \\
\hline AppSc:Business & 6 & $1.435^{* *}$ & 0.131 \\
\hline Uni:Business & 11 & $0.826^{* *}$ & 0.119 \\
\hline Uni:Computer Science & 12 & $0.574^{* *}$ & 0.125 \\
\hline AppSc:Manufacturing Engin. & 15 & $0.430^{* *}$ & 0.127 \\
\hline AppSc:Computer Science & 18 & $0.336^{* *}$ & 0.161 \\
\hline Uni:Law & 20 & $0.260^{* *}$ & 0.125 \\
\hline Uni:Economics & 30 & -0.074 & 0.134 \\
\hline Voc:Business & 31 & -0.092 & 0.143 \\
\hline Uni:Teaching & 35 & -0.449 & 0.258 \\
\hline Voc:Chemical Engin. & 37 & $-0.612^{* *}$ & 0.181 \\
\hline Voc:Medical Services & 43 & $-1.199^{* *}$ & 0.172 \\
\hline AppSc:Construction Engin. & 45 & $-1.257^{* *}$ & 0.132 \\
\hline Uni:Political Science & 50 & $-1.709^{* *}$ & 0.127 \\
\hline AppSc:Social Work & 51 & $-1.732^{* *}$ & 0.245 \\
\hline Uni:Regional Science & 59 & $-2.228^{* *}$ & 0.169 \\
\hline Uni:Music & 60 & $-2.411^{* *}$ & 0.165 \\
\hline Uni:History & 61 & $-2.566^{* *}$ & 0.167 \\
\hline Uni:Social Work & 62 & $-4.059^{* *}$ & 0.232 \\
\hline Voc:Gardening & 63 & $-4.323^{* *}$ & 0.183 \\
\hline
\end{tabular}

S.E. calculated using the delta method. Significance levels: $\quad \dagger: 10 \% \quad *: 5 \% \quad * *: 1 \%$ Source: Estimation based on German Micro Census, years 2005-2009.

Notes: Excess returns and risk are calculated using a discount rate of $(\gamma=1.03)$. Only selected fields are depicted. A full list of field is given in A12. 
Table A11: Standardized Returns, Women

\begin{tabular}{|c|c|c|c|}
\hline & Rank & $\begin{array}{c}\text { Standardized } \\
\text { Return } \\
S j\end{array}$ & S.E. \\
\hline & (1) & $(2)$ & $(3)$ \\
\hline AppSc:Management Science & 1 & $3.697^{* *}$ & 0.431 \\
\hline Uni:Medicine & 2 & $2.059^{* *}$ & 0.207 \\
\hline Uni:Dentistry & 3 & $1.941^{* *}$ & 0.158 \\
\hline AppSc:Finance and Insurance & 4 & $1.819^{* *}$ & 0.388 \\
\hline Uni:Teaching & 5 & $1.394^{* *}$ & 0.313 \\
\hline AppSc:Business & 6 & $1.159^{* *}$ & 0.245 \\
\hline AppSc:Computer Science & 9 & $0.576^{*}$ & 0.201 \\
\hline Uni:Law & 11 & 0.214 & 0.201 \\
\hline Uni:Business & 12 & 0.207 & 0.205 \\
\hline Voc:Chemical Engin. & 13 & 0.016 & 0.286 \\
\hline Uni:Computer Science & 14 & -0.017 & 0.240 \\
\hline AppSc:Social Work & 16 & -0.031 & 0.360 \\
\hline Voc:Business & 23 & -0.526 & 0.287 \\
\hline Uni:Political Science & 24 & $-0.536^{* *}$ & 0.211 \\
\hline Uni:Economics & 27 & $-0.694^{* *}$ & 0.206 \\
\hline Voc:Medical Services & 35 & $-1.075^{*}$ & 0.340 \\
\hline AppSc:Manufacturing Engin. & 42 & $-1.415^{* *}$ & 0.197 \\
\hline Voc:Personal Services & 47 & $-1.614^{* *}$ & 0.285 \\
\hline AppSc:Construction Engin. & 51 & $-1.930^{* *}$ & 0.222 \\
\hline Voc:Dentistry & 53 & $-2.301^{* *}$ & 0.304 \\
\hline Uni:Social Work & 54 & $-2.868^{* *}$ & 0.371 \\
\hline Voc:Textile & 55 & $-2.892^{* *}$ & 0.237 \\
\hline Voc:Beauty & 56 & $-3.336^{* *}$ & 0.232 \\
\hline
\end{tabular}

S.E. calculated using the delta method. Significance levels: $\quad \dagger: 10 \% \quad *: 5 \% \quad * *: 1 \%$ Source: Estimation based on German Micro Census, years 2005-2009.

Notes: Excess returns and risk are calculated using a discount rate of $\gamma=1.03$. Only selected fields are depicted. A full list of fields is given in A13. 
Table A12: Returns and standardized Returns to field of education: All fields, Men

\begin{tabular}{|c|c|c|c|c|c|c|}
\hline & \multicolumn{3}{|c|}{ Returns $E\left[\hat{R}_{j}\right]-\hat{\hat{R}}$} & \multicolumn{3}{|c|}{ Standardized Returns $S j$} \\
\hline & Rank & Return & S.E. & Rank & Return & S.E. \\
\hline Uni:Dentistry & 1 & $4.020^{* *}$ & 0.337 & 5 & $1.529^{* *}$ & 0.337 \\
\hline AppSc:Industrial Engin. & 2 & $3.984^{* *}$ & 0.269 & 2 & $2.082^{* *}$ & 0.269 \\
\hline AppSc:Management Science & 3 & $3.890^{* *}$ & 0.308 & 1 & $2.836^{* *}$ & 0.308 \\
\hline Uni:Medicine & 4 & $3.672^{* *}$ & 0.313 & 4 & $1.608^{* *}$ & 0.313 \\
\hline AppSc:Business & 5 & $2.936^{* *}$ & 0.268 & 6 & $1.435^{* *}$ & 0.268 \\
\hline AppSc:Finance and Insurance & 6 & $2.815^{* *}$ & 0.298 & 3 & $1.719^{* *}$ & 0.298 \\
\hline Voc:Maths & 7 & $2.363^{* *}$ & 0.270 & 10 & $1.179^{* *}$ & 0.270 \\
\hline AppSc:Supply Engin. & 8 & $2.323^{* *}$ & 0.256 & 7 & $1.343^{* *}$ & 0.256 \\
\hline AppSc:Electrical Engin. & 9 & $2.275^{* *}$ & 0.252 & 8 & $1.305^{* *}$ & 0.252 \\
\hline Voc:Finance and Insurance & 10 & $2.189^{* *}$ & 0.314 & 9 & $1.208^{* *}$ & 0.314 \\
\hline Uni:Business & 11 & $1.848^{* *}$ & 0.265 & 11 & $0.826^{*}$ & 0.265 \\
\hline Uni:Computer Science & 12 & $1.077^{* *}$ & 0.234 & 12 & $0.574^{\dagger}$ & 0.234 \\
\hline Uni:Industrial Engin. & 13 & $1.055^{* *}$ & 0.262 & 13 & $0.517^{\dagger}$ & 0.262 \\
\hline AppSc:Chemical Engin. & 14 & $0.909 * *$ & 0.252 & 14 & $0.501^{\dagger}$ & 0.252 \\
\hline AppSc:Manufacturing Engin. & 15 & $0.809^{* *}$ & 0.239 & 15 & 0.430 & 0.239 \\
\hline Voc:Accounting & 16 & $0.792^{*}$ & 0.282 & 16 & 0.387 & 0.282 \\
\hline Uni:Law & 17 & $0.626^{\dagger}$ & 0.302 & 20 & 0.260 & 0.302 \\
\hline AppSc:Computer Science & 18 & $0.586^{\dagger}$ & 0.281 & 18 & 0.336 & 0.281 \\
\hline Voc:Computer Science & 19 & 0.459 & 0.319 & 19 & 0.267 & 0.319 \\
\hline Voc:Public Security & 20 & 0.458 & 0.312 & 17 & 0.341 & 0.312 \\
\hline Voc:Management Science & 21 & 0.353 & 0.303 & 21 & 0.196 & 0.303 \\
\hline Uni:Chemistry & 22 & 0.219 & 0.308 & 22 & 0.118 & 0.308 \\
\hline Voc:Transport & 23 & 0.202 & 0.280 & 25 & 0.086 & 0.280 \\
\hline Uni:Manufacturing Engin. & 24 & 0.201 & 0.294 & 23 & 0.106 & 0.294 \\
\hline Voc:Manufacturing Engin. & 25 & 0.170 & 0.263 & 24 & 0.098 & 0.263 \\
\hline Uni:Supply Engin. & 26 & 0.144 & 0.292 & 26 & 0.083 & 0.292 \\
\hline Uni:Physics & 27 & 0.102 & 0.291 & 27 & 0.058 & 0.291 \\
\hline AppSc:Precision Engin. & 28 & -0.113 & 0.238 & 28 & -0.065 & 0.238 \\
\hline Uni:Maths & 29 & -0.138 & 0.303 & 29 & -0.071 & 0.303 \\
\hline Uni:Economics & 30 & -0.175 & 0.315 & 30 & -0.074 & 0.315 \\
\hline Voc:Business & 31 & -0.185 & 0.286 & 31 & -0.092 & 0.286 \\
\hline Uni:Teaching & 32 & -0.708 & 0.407 & 35 & -0.449 & 0.407 \\
\hline Voc:Electrical Engin. & 33 & $-0.730^{\dagger}$ & 0.285 & 33 & -0.414 & 0.285 \\
\hline AppSc:Maths & 34 & $-0.774^{*}$ & 0.240 & 32 & -0.395 & 0.240 \\
\hline Uni:Chemical Engin. & 35 & $-0.857^{*}$ & 0.305 & 36 & -0.462 & 0.305 \\
\hline Uni:Psychology & 36 & $-0.898^{\dagger}$ & 0.362 & 34 & -0.445 & 0.362 \\
\hline Voc:Chemical Engin. & 37 & $-0.986^{* *}$ & 0.292 & 37 & $-0.612^{\dagger}$ & 0.292 \\
\hline Voc:Precision Engin. & 38 & $-1.336^{* *}$ & 0.258 & 38 & $-0.767^{*}$ & 0.258 \\
\hline Uni:Electrical Engin. & 39 & $-1.536^{* *}$ & 0.289 & 39 & $-0.777^{*}$ & 0.289 \\
\hline Voc:Trade and Logistic & 40 & $-1.688^{* *}$ & 0.294 & 40 & $-0.860^{*}$ & 0.294 \\
\hline Voc:Supply Engin. & 41 & $-1.841^{* *}$ & 0.264 & 42 & $-1.020^{* *}$ & 0.264 \\
\hline Uni:Anglistic & 42 & $-1.965^{* *}$ & 0.288 & 41 & $-0.994^{* *}$ & 0.288 \\
\hline Voc:Nursing & 43 & $-2.167^{* *}$ & 0.309 & 49 & $-1.606^{* *}$ & 0.309 \\
\hline Voc:Medical Services & 44 & $-2.205^{* *}$ & 0.316 & 43 & $-1.199^{* *}$ & 0.316 \\
\hline AppSc:Social Work & 45 & $-2.299^{* *}$ & 0.325 & 51 & $-1.732^{* *}$ & 0.325 \\
\hline AppSc:Construction Engin. & 46 & $-2.328^{* *}$ & 0.245 & 45 & $-1.257^{* *}$ & 0.245 \\
\hline Uni:Biology & 47 & $-2.456^{* *}$ & 0.275 & 44 & $-1.235^{* *}$ & 0.275 \\
\hline Uni:Construction Engin. & 48 & $-2.549^{* *}$ & 0.298 & 46 & $-1.280^{* *}$ & 0.298 \\
\hline AppSc:Architecture & 49 & $-2.555^{* *}$ & 0.255 & 47 & $-1.296^{* *}$ & 0.255 \\
\hline Voc:Transport Engin. & 50 & $-2.869^{* *}$ & 0.256 & 48 & $-1.560^{* *}$ & 0.256 \\
\hline Uni:Geo Science & 51 & $-3.404^{* *}$ & 0.307 & 52 & $-1.852^{* *}$ & 0.307 \\
\hline Uni:Educational Science & 52 & $-3.505^{* *}$ & 0.371 & 57 & $-2.154^{* *}$ & 0.371 \\
\hline Voc:Media & 53 & $-3.702^{* *}$ & 0.297 & 53 & $-1.886^{* *}$ & 0.297 \\
\hline Uni:Political Science & 54 & $-3.777^{* *}$ & 0.280 & 50 & $-1.709^{* *}$ & 0.280 \\
\hline Uni:Architecture & 55 & $-3.957^{* *}$ & 0.308 & 54 & $-1.918^{* *}$ & 0.308 \\
\hline Uni:German Literature & 56 & $-4.036^{* *}$ & 0.339 & 55 & $-2.050^{* *}$ & 0.339 \\
\hline Voc:Construction Engin. & 57 & $-4.079^{* *}$ & 0.259 & 58 & $-2.221^{* *}$ & 0.259 \\
\hline Voc:Hotel Restaurant & 58 & $-4.212^{* *}$ & 0.242 & 56 & $-2.056^{* *}$ & 0.242 \\
\hline Uni:Regional Science & 59 & $-4.344^{* *}$ & 0.330 & 59 & $-2.228^{* *}$ & 0.330 \\
\hline Uni:History & 60 & $-4.722^{* *}$ & 0.307 & 61 & $-2.566^{* *}$ & 0.307 \\
\hline Uni:Music & 61 & $-5.139^{* *}$ & 0.353 & 60 & $-2.411^{* *}$ & 0.353 \\
\hline Uni:Social Work & 62 & $-6.554^{* *}$ & 0.374 & 62 & $-4.059^{* *}$ & 0.374 \\
\hline Voc:Gardening & 63 & $-6.781^{* *}$ & 0.287 & 63 & $-4.323^{* *}$ & 0.287 \\
\hline Total number of Fields & 63 & & & 63 & & \\
\hline
\end{tabular}

S.E. calculated using the delta method. Significance levels: $\quad \dagger: 10 \% \quad *: 5 \% \quad * *: 1 \%$

Source: Estimation based on German Micro Census, years 2005-2009

Notes: Excess returns and risk are calculated using 3 discount rate of $\gamma=1.03$. 
Table A13: Returns and standardized Returns: All fields, Women

\begin{tabular}{|c|c|c|c|c|c|c|}
\hline & \multicolumn{3}{|c|}{ Returns $E\left[\hat{R}_{j}\right]-\hat{\hat{R}}$} & \multicolumn{3}{|c|}{ Standardized Returns $S j$} \\
\hline & Rank & Return & S.E. & Rank & Return & S.E. \\
\hline Uni:Dentistry & 1 & $4.994^{* *}$ & 0.408 & 3 & $1.941^{* *}$ & 0.408 \\
\hline AppSc:Management Science & 2 & $4.800^{* *}$ & 0.560 & 1 & $3.697^{* *}$ & 0.560 \\
\hline Uni:Medicine & 3 & $4.110^{* *}$ & 0.413 & 2 & $2.059^{* *}$ & 0.413 \\
\hline AppSc:Finance and Insurance & 4 & $2.570^{* *}$ & 0.548 & 4 & $1.819^{* *}$ & 0.548 \\
\hline Uni:Teaching & 5 & $2.401^{* *}$ & 0.540 & 5 & $1.394^{*}$ & 0.540 \\
\hline AppSc:Business & 6 & $2.076^{* *}$ & 0.439 & 6 & $1.159^{*}$ & 0.439 \\
\hline Voc:Finance and Insurance & 7 & $1.225^{\dagger}$ & 0.551 & 7 & 0.807 & 0.551 \\
\hline AppSc:Computer Science & 8 & $1.108^{*}$ & 0.387 & 9 & 0.576 & 0.387 \\
\hline Voc:Anglistic & 9 & $1.081^{\dagger}$ & 0.470 & 8 & 0.618 & 0.470 \\
\hline Voc:Marketing & 10 & 0.689 & 0.466 & 10 & 0.397 & 0.466 \\
\hline Uni:Law & 11 & 0.466 & 0.436 & 11 & 0.214 & 0.436 \\
\hline Uni:Business & 12 & 0.405 & 0.402 & 12 & 0.207 & 0.402 \\
\hline Voc:Chemical Engin. & 13 & 0.027 & 0.478 & 13 & 0.016 & 0.478 \\
\hline Uni:Computer Science & 14 & -0.028 & 0.404 & 14 & -0.017 & 0.404 \\
\hline Uni:Psychology & 15 & -0.037 & 0.476 & 15 & -0.021 & 0.476 \\
\hline AppSc:Social Work & 16 & -0.045 & 0.522 & 16 & -0.031 & 0.522 \\
\hline Voc:Transport & 17 & -0.060 & 0.467 & 17 & -0.039 & 0.467 \\
\hline Voc:Nursing & 18 & -0.148 & 0.519 & 19 & -0.107 & 0.519 \\
\hline Voc:Management Science & 19 & -0.155 & 0.527 & 18 & -0.101 & 0.527 \\
\hline Voc:Accounting & 20 & -0.304 & 0.516 & 20 & -0.174 & 0.516 \\
\hline Uni:Chemistry & 21 & -0.680 & 0.437 & 21 & -0.374 & 0.437 \\
\hline Voc:Business & 22 & -0.874 & 0.476 & 23 & -0.526 & 0.476 \\
\hline Uni:Maths & 23 & $-0.884^{\dagger}$ & 0.415 & 22 & -0.478 & 0.415 \\
\hline Uni:Political Science & 24 & $-1.007^{\dagger}$ & 0.397 & 24 & -0.536 & 0.397 \\
\hline Voc:Manufacturing Engin. & 25 & $-1.010^{\dagger}$ & 0.451 & 25 & -0.603 & 0.451 \\
\hline Voc:Social Work & 26 & -1.039 & 0.540 & 28 & -0.720 & 0.540 \\
\hline AppSc:Educational Science & 27 & $-1.115^{\dagger}$ & 0.501 & 26 & -0.686 & 0.501 \\
\hline Voc:Media & 28 & $-1.357^{*}$ & 0.464 & 29 & -0.735 & 0.464 \\
\hline Uni:Economics & 29 & $-1.423^{* *}$ & 0.423 & 27 & -0.694 & 0.423 \\
\hline Voc:Educational Science & 30 & $-1.532^{*}$ & 0.534 & 37 & $-1.114^{\dagger}$ & 0.534 \\
\hline Uni:Biology & 31 & $-1.656^{* *}$ & 0.433 & 30 & $-0.935^{\dagger}$ & 0.433 \\
\hline Uni:Educational Science & 32 & $-1.688^{* *}$ & 0.511 & 32 & -0.990 & 0.511 \\
\hline Voc:Medical Services & 33 & $-1.708^{*}$ & 0.541 & 35 & $-1.075^{\dagger}$ & 0.541 \\
\hline Voc:Trade and Logistic & 34 & $-1.711^{* *}$ & 0.491 & 33 & $-1.022^{\dagger}$ & 0.491 \\
\hline Voc:Tourism & 35 & $-1.751^{* *}$ & 0.485 & 36 & $-1.112^{\dagger}$ & 0.485 \\
\hline Uni:German Literature & 36 & $-1.828^{* *}$ & 0.453 & 31 & $-0.981^{\dagger}$ & 0.453 \\
\hline Uni:Anglistic & 37 & $-2.035^{* *}$ & 0.432 & 34 & $-1.037^{\dagger}$ & 0.432 \\
\hline Uni:Chemical Engin. & 38 & $-2.264^{* *}$ & 0.428 & 39 & $-1.223^{*}$ & 0.428 \\
\hline Uni:Manufacturing Engin. & 39 & $-2.407^{* *}$ & 0.401 & 38 & $-1.123^{*}$ & 0.401 \\
\hline Uni:Geo Science & 40 & $-2.409^{* *}$ & 0.448 & 46 & $-1.508^{* *}$ & 0.448 \\
\hline Voc:Office Assistant & 41 & $-2.416^{* *}$ & 0.498 & 45 & $-1.484^{*}$ & 0.498 \\
\hline AppSc:Architecture & 42 & $-2.425^{* *}$ & 0.449 & 43 & $-1.434^{*}$ & 0.449 \\
\hline AppSc:Maths & 43 & $-2.526^{* *}$ & 0.395 & 40 & $-1.320^{* *}$ & 0.395 \\
\hline AppSc:Manufacturing Engin. & 44 & $-2.567^{* *}$ & 0.357 & 42 & $-1.415^{* *}$ & 0.357 \\
\hline Uni:History & 45 & $-2.619^{* *}$ & 0.426 & 41 & $-1.371^{*}$ & 0.426 \\
\hline Voc:Hotel Restaurant & 46 & $-2.778^{* *}$ & 0.441 & 44 & $-1.454^{* *}$ & 0.441 \\
\hline Voc:Personal Services & 47 & $-3.012^{* *}$ & 0.531 & 47 & $-1.614^{*}$ & 0.531 \\
\hline Uni:Regional Science & 48 & $-3.089^{* *}$ & 0.427 & 49 & $-1.869^{* *}$ & 0.427 \\
\hline AppSc:Construction Engin. & 49 & $-3.323^{* *}$ & 0.382 & 51 & $-1.930^{* *}$ & 0.382 \\
\hline Uni:Construction Engin. & 50 & $-3.587^{* *}$ & 0.411 & 52 & $-2.127^{* *}$ & 0.411 \\
\hline Uni:Architecture & 51 & $-3.609^{* *}$ & 0.412 & 50 & $-1.882^{* *}$ & 0.412 \\
\hline Uni:Music & 52 & $-3.725^{* *}$ & 0.477 & 48 & $-1.857^{* *}$ & 0.477 \\
\hline Voc:Dentistry & 53 & $-3.769^{* *}$ & 0.499 & 53 & $-2.301^{* *}$ & 0.499 \\
\hline Uni:Social Work & 54 & $-4.038^{* *}$ & 0.522 & 54 & $-2.868^{* *}$ & 0.522 \\
\hline Voc:Textile & 55 & $-5.087^{* *}$ & 0.416 & 55 & $-2.892^{* *}$ & 0.416 \\
\hline Voc:Beauty & 56 & $-6.617^{* *}$ & 0.459 & 56 & $-3.336^{* *}$ & 0.459 \\
\hline Total number of Fields & 56 & & & 56 & & \\
\hline S.E. calculated using the delta & thoc & ficance & $\dagger:$ & & $* *: 19$ & \\
\hline
\end{tabular}


Figure B1: Age-earnings profile: Men

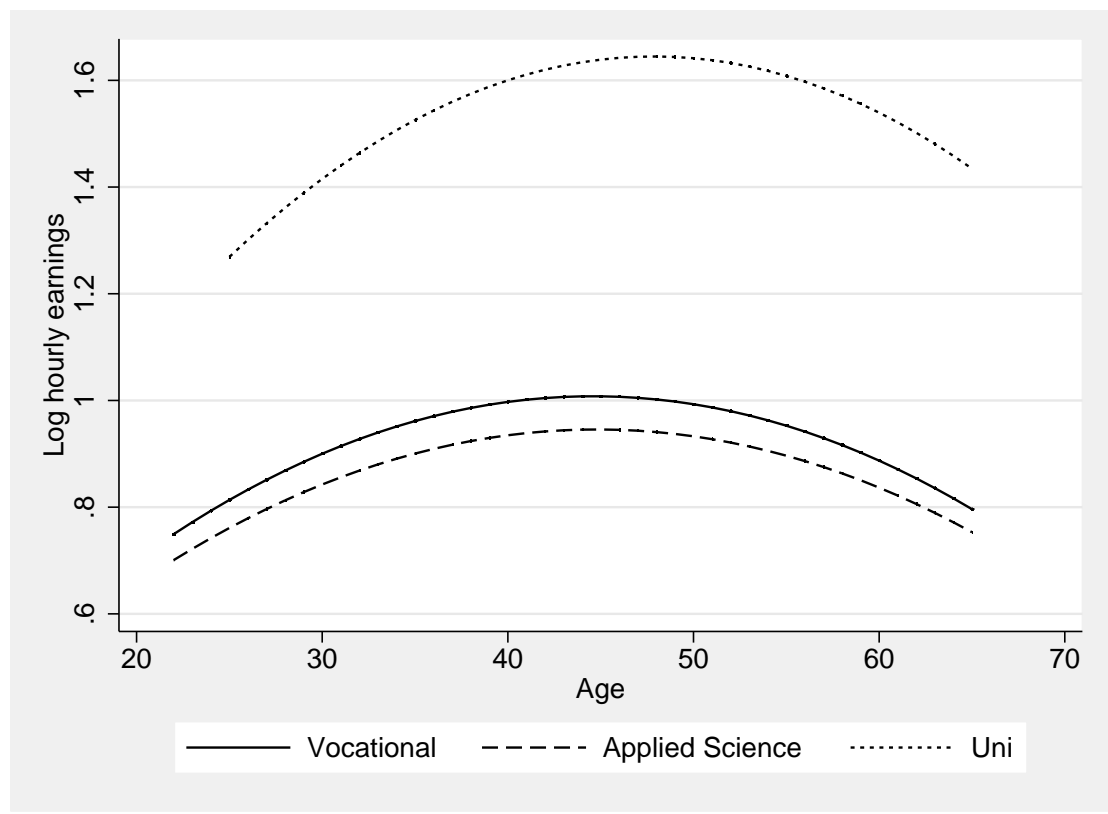

Figure B2: Age-earnings profile: Women

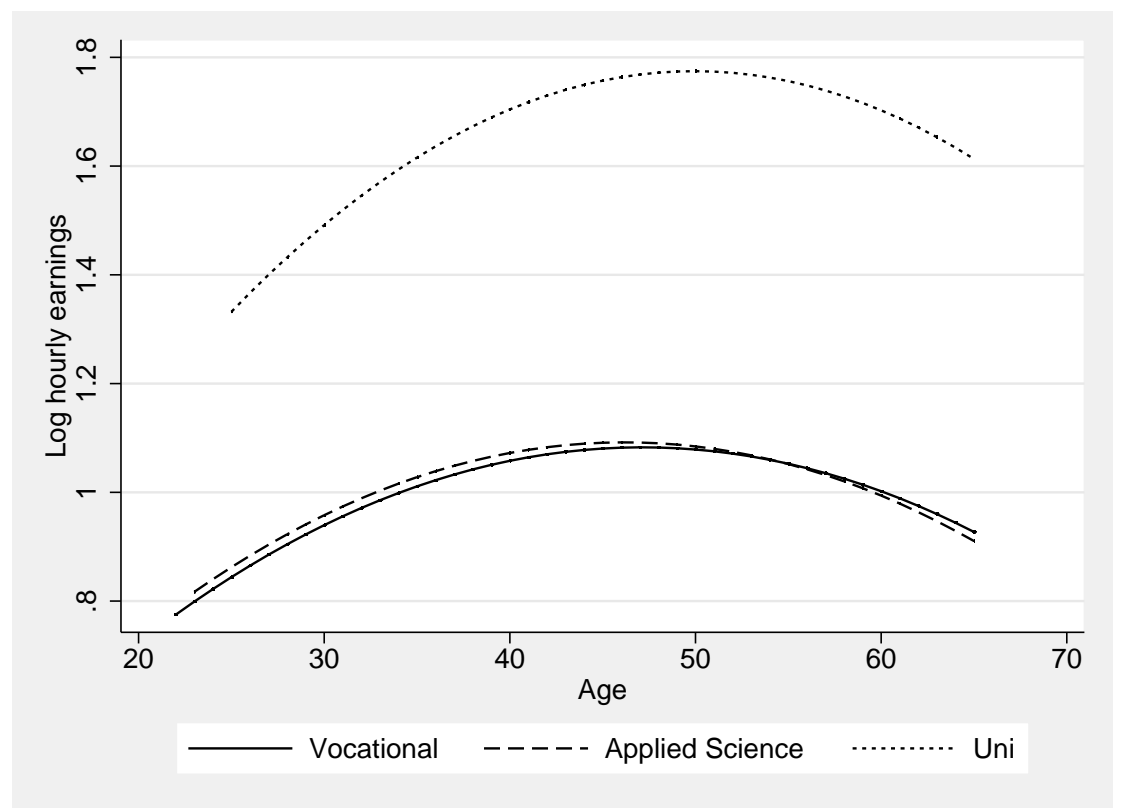

